\title{
Delenda est haec Carthago: The Ostend Company As A Problem Of European Great Power Politics (1722-1727) ${ }^{1}$
}

\author{
Dr. Frederik Dhondt \\ Legal History Institute, Ghent University
}

\section{Summary}

The Ostend Company (1722-1731) is a symbol of present-day Belgium's strangling by European Great Power politics in the Ancien Régime, and more specifically of the limitations imposed on the Southern Netherlands by the Dutch Republic in 1648. The present contribution analyses the right of Emperor Charles VI to send out ships to the East Indies. Pamphlets by Abraham Westerveen and Jean Barbeyrac, argued for the exclusion of the Southern Netherlands based on the Treaty of Munster. Against this, Patrice de Neny and Jean du Mont invoked the peremptory character of the natural law-rules governing free trade. However, the Treaty of Commerce concluded between Charles VI and Philip V, King of Spain, on 1 May 1725, constituted a strong basis to refute the Dutch attacks. Yet, norm hierarchy between the balance of power inscribed in the Peace of Utrecht and secondary bilateral treaties between sovereigns dominated multilateral diplomacy after 1713 and prejudiced the "Belgian" East India trade.

\section{Keywords}

International Law, Legal History, International Relations

\section{Introduction $^{2}$}

[Les Nations] les plus prudentes cherchent à se procurer par des Traités, les sécours \& les avantages, que la Loi Naturelle leur assureroit, si les pernicieux conseils d'une fausse Politique ne la rendoient inefficace.

Vattel, Le Droit des Gens ${ }^{3}$

Concerning the OSTEND COMPANY [...] DELEND A EST HAEC CARTHAGO

The Importance of the Ostend-Company consider'd, $1726^{4}$

In Belgian historiography, the Imperial East India Company created in Ostend (1722-1731) is often presented as an example of the sorry fate the Southern Netherlands had to suffer from the Dutch Revolt to the end of the French Revolutionary Wars ${ }^{5}$. Politically relegated to the status of but one of several

\footnotetext{
${ }^{1}$ Abbreviations used in this article : CUD (Corps Universel Diplomatique du Droit des Gens, see footnote 6); NA (National Archives), SP (State Papers Foreign) (see footnote 190); AMAE (Archives du Ministère des Affaires Étrangères et Européennes), $C P$ (Correspondance Politique), $M \& D$ (Mémoires et Documents) (see footnote 192).

2 The present article has been presented in an earlier stage to the Dutch-Belgian Study Group for the Reception of Roman Law at Leiden University on 21 October 2011. My thanks go to the audience for their remarks on my initial ideas, as well as to Dirk Heirbaut, Georges Martyn, Rik Opsommer, Magnus Ressel and Klaas Van Gelder, who commented on a later version of the draft.

${ }^{3}$ Emer DE VATTEL, Le droit des gens ou principes de la loi naturelle Appliqués à la Conduite \& aux Affaires des Nations \& des Souverains. Ouvrage qui conduit à developer les veritables Interêts des Puissances, Leide, Aux dépens de la Compagnie, 1758, 2e éd., Book II, \152.

4 The Importance of the Ostend-Company consider'd, London: Roberts, 1726, p. 52.

${ }^{5}$ E.g. "La Belgique, sacrifiée sans pitié lors d'une négociation dont elle avait été exclue, se trouvait quasi étranglée, en attendant de devenir le champ de bataille de l'Europe”; Georges-Henri DumONT, L'Épopée de la Compagnie d'Ostende 1723-1727, Bruxelles, Le Cri, 2000, p. 10.
} 
dominions ruled by a far-away monarch, economically strangled on the conditions of the Treaties of Munster", the former "staple of Europe" with cities as Antwerp, Malines, Brussels or Ghent had become a dormant territory in the heart of Europe, and nothing more than the privileged battlefield for first-rank powers such as France, Spain and Austria, Britain or the Dutch Republic.

The present contribution argues the fate of the Ostend Company was not a bilateral quarrel between North and South, dictated by anonymous or coincidental arrangements between Great Powers 7 , symbolising the triumph of Realpolitik over principles of natural law ${ }^{8}$. A reductionist view of the Ostend conflict ignores the European structure of international relations. On the one hand, the combination of political events and the Dutch Republic's own legal logic offered a possibility for "Belgian" trade with the East Indies to flourish. On the other hand, explaining the Company's demise by the Emperor's desire to see his daughters succeed him in the Habsburg hereditary lands, is only a fragmentary explanation. The predominance of an international guarantee for his "Pragmatic Sanction" was not a mere chimera pursued by Charles $\mathrm{VI}^{9}$, but a consequence of a quest for international legitimacy shared by the main actors ${ }^{10}$, and of the changing legal discourse of the Peace of Utrecht (11 April 171311). To this end, an analysis of bilateral legal pamphlet literature ${ }^{12}$ (I) ought to be complemented with diplomatic correspondence and the operation of international law in minds (II) within the European Society of Princes ${ }^{13}$.

The commercial enterprises leading to the Ostend Company were launched by Thomas Ray, a naturalised Irishman who had landed in Ostend in 1698, joining a growing disparate group of Irish merchants ${ }^{14}$. Ray found financial support in Ghent, Bruges and Dunkirk, to send an Ostend-based ship, the Sint-Mattheus, to

6 Treaty between Philip IV and the States-General, Munster, 30 January 1648, Du MONT DE CARELSKroon (ed.), Corps Universel Diplomatique du Droit des Gens, contenant un recueil des traitez d'alliance, de paix, de treve, de neutralité, de commerce, d'échange, de protection \& de Garantie, de toutes les Conventions, Transactions, Pactes, Concordats, \& autres Contrats, qui ont été faits en Europe, depuis le Regne de l'Empereur Charlemagne jusques à present [Further: CUD], The Hague, Husson \& Levier, 1728 , vI/1, nr. CCXXXI, p. 429-441.

${ }^{7}$ Frans De PAUw, Het Mare Liberum van Grotius en Pattijn, Brugge, Die Keure, 1960 (Vlaamse Rechtskundige Bibliotheek; Nieuwe Reeks), p. 231.

8 The present contribution is limited to the political and legal discussions around the Company. For commercial aspects, I refer to Eduard J. BAELS, De generale keizerlijke en koninklijke Indische Compagnie gevestigd in de Oostenrijkse Nederlanden genaamd de Oostendse Compagnie, Oostende, Erel, 1972; Karel DEGRYSE, "De Oostendse Chinahandel (1718-1735), in Revue Belge de Philologie et d'Histoire-Belgisch Tijdschrift voor Filologie en Geschiedenis, LII (1974), Nr. 2, 306-347; John EveraERT, "Les companies rivales des grandes Compagnies des Indes. Le défi de la Compagnie d'Ostende (1715-1745), in Christian BuCHET, Jean MEYER \& Jean-Pierre POussou (dir.), La puissance maritime. Actes du colloque international tenu à l'Institut Catholique de Paris, 13-15 décembre 2001, Paris, PUPS, 2004, p. 415422 ; Jan PARMENTIER, De maritieme handel en visserij in Oostende tijdens de achttiende eeun : een prosopografische analyse van de internationale Oostendse handelswereld, 1700-1794 (diss. doc.), Gent: UGent, 2001, 4 v. ; Michael W. SERRUYS, "Oostende en de Generale Indische Compagnie. De opbloei en neergang van een koloniale handelshaven (1713-1740)", Tijdschrift voor Zeegeschiedenis XXIV (2005), Nr. 1, p. 43-59.

${ }_{9}$ Henri Pirenne, Histoire de Belgique, Bruxelles, Lamertin, 1926, V, p. 198: "Personne ne s'intéressait, en dehors de Hambourg, à la Compagnie d'Ostende. D'ailleurs les considérations dynastiques commençaient à déterminer la politique de l'empereur [...] il voulait passionnément assurer sa succession."

10 Johannes Kunisch, Staatsverfassung und Mächtepolitik, Berlin, Duncker \& Humblot, 1979 (Historische Forschungen; 15), p. 54. See as well Charles IngRAO, "The Pragmatic Sanction and the Theresian succession: A re-evaluation", in Études danubiennes IX (1993), p. 145-161.

11 Treaties of Peace between Louis XIV and John V of Portugal, Louis XIV and Frederick William I of Prussia, Louis XIV and Queen Anne, Louis XIV and Victor II Amadeus of Savoy, Louis XIV and the States-General, 11 April 1713, CUD VIII/1, nrs. CLII-CLVII, p. 353-386.

12 For a broader survey of pamphlets on the Ostend Company, I refer to Kris VAN DER MYNSBRUGGE, De pamflettenoorlog rond de Oostendse Compagnie, UGent: Faculty of Arts and Philosophy (master thesis in History), 19992000, p. 68-123 and 175-182. My thanks go to one of the anonymous referees for this article.

${ }^{13}$ Lucien BÉLY, La Société des Princes XVIe-XVIIIe siècle, Paris, Fayard, 1999; Ragnhild HATTON, "Louis XIV and his fellow monarchs", in HATTON (ed.), Louis XIV and Europe, London, Macmillan, 1976, p. 16-59.

14 PARMENTIER, "The Irish Connection The Irish Merchant Community in Ostend and Bruges during the late Seventeenth and Eighteenth Centuries" in Eighteenth Century Ireland Xx (2005), p. 37. 
Surate in the East Indies, on 17 June 171415. When the ship left Ostend, the Peace Treaty of Rastatt had been concluded three months earlier ${ }^{16}$. Louis XIV and Charles VI, representing the two main contending parties in the conflict over the Spanish Succession (1659-1715), had just put an end to the latest continentwide war, which had divided Europe from 1701 on. Charles had been allotted the Spanish Netherlands, or the remaining ten provinces loyal to their Habsburg ruler after the split of the XVII Provinces ${ }^{17}$. During the war, as the Imperial candidate for the Spanish throne, Charles had claimed much more than merely the territories by the North Sea. The partition of the Spanish inheritance between Charles and the French candidate, Philip of Anjou, was, however, inevitable ${ }^{18}$. Neither the House of Habsburg nor that of Bourbon could be allowed to dominate the continent, threatening to engulf the other sovereigns. The expedition left before the conclusion of the Treaty of Antwerp on 15 November 171519, which opened the way to the effective transfer of the Southern Netherlands to Charles. From 1706 on, effective control of most of the "Belgian" provinces had been exercised by the joint Anglo-Dutch occupation forces that had driven out those of Louis XIV and his grandson ${ }^{20}$.

If the Habsburg claim on Spain had fully succeeded, Charles VI would have ruled over circa the same territories as, two centuries earlier, Charles $\mathrm{V}^{21}$. Control of the Burgundian inheritance, which served as the building block of Habsburg power in the late fifteenth and early sixteenth centuries, was crucial in the contest between Charles VI and the new King of Spain, Philip V (1683-1746)22.

Second, Thomas Ray had all reason to move to a Catholic country. As a naturalised Irishman, he can be seen as part of the "Jacobite diaspora"23, which supported the claims of James II, the chased Catholic King of England (1633-1701). James fled to France in 1688. The Battle of the Boyne (12 July 1690) consolidated the British isles for his rival, William III of Orange (1650-1702). With the installation of Georg Ludwig of Hanover (1660-1727) as King of England ${ }^{24}$ accepted by all major European powers by August 1714, the chances of the Stuarts ever returning to the throne were significantly reduced. In order

\footnotetext{
15 Ibid., p. 38-42.

16 Peace Treaty between Charles VI and Louis XIV, Rastatt, 6 March 1714, CUD, VIII/1, nr. CLXX, 415-423.

${ }^{17}$ Klaas VAN GELDER, "L'empereur Charles VI et "l'héritage anjouin" dans les Pays-Bas méridionaux (1716-1725)", in Revue d'bistoire moderne et contemporaine LVIII (2011), No. 1, p. 53-79.

18 Antonio Álvarez-Ossorio, Bernardo J. García García \& Virginia LeÓn SANZ (eds.), La guerra de Sucesión por la Monarquía de España, Madrid, Fundación Carlos de Amberes, 2007; Frederik DHONDT, "From Contract to Treaty: The Legal Transformation of the Spanish Succession, 1659-1715", in Journal of the History of International Law-Revue d'histoire du droit international [Further: JHIL] XIII (2011), No. 2, 347-374; Marie-Françoise MAQUART, Le réseau français à la cour de Charles II d'Espagne : jeux diplomatiques de fin de règne - 1696-1700 (diss. doc.), Villeneuve-d'Asq, Presses Universitaires du Septentrion, 1999.

${ }^{19}$ Treaty of the Barrier between Charles VI, George I and the States-General, Antwerp, 15 November 1715, CUD, VIII/1, nr. CLXXX, p. 458-468.

20 Reginald DE SCHRYVER, "Who had sovereignty in the Southern Netherlands during the War of the Spanish Succession (1700-1715)?”, in X (ed.), Liber amicorum Jan Buntinx. Recht en instellingen in de oude Nederlanden tijdens de middeleeuwen en de Nieuwe Tijd, Leuven: Universitaire Pers, 1981, 483-497; VAN GELDER, "De Vooght versus Sersanders. De strijd om het presidentschap van de Raad van Vlaanderen en het probleem van de 'Anjouaanse' benoemingen in de Oostenrijkse Nederlanden (1716-1725)", in Pro Memorie. Bijdragen tot de rechtsgeschiedenis der Nederlanden, XII (2010), p. 15-35.

${ }^{21}$ LEÓn SANZ, Carlos VI. El Emperador que no pudo ser Rey de España, Madrid, Aguilar, 2003.

22 E.g. discussions on the Golden Fleece at the Cambrai conference, F. DHONDT, Balance of Power and International Law. European Diplomacy and the Elaboration of International Order, $18^{\text {th }}$ Century and Post 1945 (diss. doc.), Ghent, UGent, 2013, p. 248-251 (à paraitre comme Balance of Power and Norm Hierarchy. Franco-British Diplomacy after the Peace of Utrecht (1713), Leiden: Martinus Nijhoff, 2015 (Studies in the History of International Law; 7); Elena Postiga-o Castellanos, "El cisma del toisón. Dinastía y orden (1700-1748)", in Pablo FernánDeZAlbaladejo (ed.), Los Borbones. Dinastía y memoria de nación en la España del Siglo XVIII, Madrid: Marcial Pons, 2001, 331-380; Annemarie WEBER, Der Österreichische Orden vom Goldenen Vliess. Geschichte und Probleme (diss. doc.), Bonn, Friedrich-Wilhelms-Universität Bonn, 1971.

23 Patrick Clarke DE Dromantin, Les réfugiés jacobites dans la France du XVIIIe siècle: l'exode de toute une noblesse pour cause de religion, Pessac: Presses universitaires de Bordeaux, 2005.

${ }^{24}$ HatTon, George I, New Haven (Conn.), Yale UP, 2001 [1978] (Yale English Monarchs).
} 
to return to Britain, James "III" (1688-1766), son of the deceased Catholic monarch, could only hope for a continental and Catholic coalition against Britain. To this effect, his supporters actively lobbied the courts of Versailles, Madrid and Rome ${ }^{25}$. It should come as no surprise that a first series of British statutes against the Ostend enterprise were issued on 17 March 1714 and 18 October 17126. The Jacobite network was not only political, but also commercial. It spanned the continent and was important for trade between Spain, Portugal, France and Britain ${ }^{27}$. Nine out of ten members of the officer's council on the Sint-Mattheus were of Irish origin ${ }^{28}$. In the future Ostend Company's ventures, one sailor out of five ${ }^{29}$.

The scene seemed set for a classical opposition between the Protestant Maritime Powers and one of the two Catholic monarchs in Versailles or Vienna. After Louis XIV's decease in September 1715, Britain was busy negotiating a new deal with Charles VI, involving Italy and the recognition of the Emperor's succession $^{30}$. The 1715 Barrier Treaty ${ }^{31}$ between the Maritime Powers and Charles VI was set up as a safeguard against French invasion, in order to prevent the scenario of the previous wars ${ }^{32}$. Direct French aggression against the Dutch Republic had to be rendered impossible, thanks to the occupation of a string of fortresses, paid for by Charles VI ${ }^{33}$.

Yet, a decisive combination of issues caused George I to change sides and abandon his reconciliation with the Emperor. In France, Louis XIV's death had opened the way for a Regency, assumed by the Duke of Orléans (1674-1723), cousin to the late Sun King. France's regime was a matter of consensus between the remaining court parties ${ }^{34}$. Philip of Orléans had all advantage in keeping out Philip of Anjou, Louis XIV's second grandson, who ruled in Spain since 1700. As King of Spain, Philip V did not want to abandon the dream to return to Versailles and claim the crown. He challenged the validity of the British-imposed

${ }^{25}$ Basil Williams, Stanhope: A Study in Eighteenth-Century War and Diplomacy, Oxford, Clarendon Press, 1932, p. $212-213$.

${ }^{26}$ Dates refer to the Old Style or Julian calendar, used in Britain until 1756. Gerald B. HERTZ, "England and the Ostend Company", in English Historical Review [further: EHR] XXII (1907), No. 86 (Apr), p. 255-279.

${ }^{27}$ PARMENTIER, "The Irish Connection", op. cit., p. 53.

${ }^{28}$ Ibid., p. 41.

${ }^{29}$ Ibid., p. 42.

30 Theo GeHLING, Ein englischer Diplomat am Kaiserhof zu Wien, Francois Louis de Pesne, Seigneur de SaintSaphorin, als englischer Resident am Wiener Hof, 1718-1727, Bonn, Röhrscheid Verlag, 1964 (Bonner historische Forschungen. Bd. 25) p. 119, 123; Derek MCKAY, Allies of convenience: diplomatic relations between Great Britain and Austria, 1714-1719, New York, Garland, 1986 (Outstanding theses from the London School of Economics and Political Sciences). In the line of the Grand Alliance against Louis XIV, George I's enthronization as British monarch could be seen as a sign of a stronger Austro-British relationship. Georg Ludwig had supported Charles' claims to the Spanish inheritance and continued the struggle at the Emperor's side after the British defected from the Alliance (HATTON, Diplomatic relations between Great Britain and the Dutch Republic, 1714-1721, London, East and West, 1950).

31 Traité entre Charles VI. Empereur des Romains \& Roi Catholique des Espagnes d'une part, George Roi de la Grande-Bretagne \& les Seigneurs Etats Generaux des Provinces-Unies des Païs-Bas, d'autre part, pour la Restitution, à sa Majesté Impériale \& Catholique de tout le Païs-Bas Espagnol, sous la reserve d'une forte \& solide Barrière aux mêmes Païs-Bas en faveur de Leurs Hautes Puissances, Antwerp, 15 November 1715, CUD, VIII/1, nr. CLXXX, p. 458-468.

32 Thirty Years War (1635), War of Devolution (1667), Dutch War (1672), War of the Réunions (1683), Nine Years' War (1688) and War of the Spanish Succession (1701). See John A. LYNN, The Wars of Louis XIV, $1667-$ 1714, London, Longman, 1999 (Modern wars in perspective).

33 A sum amounting to a third of the Southern Netherlands' annual budget (VAN GELDER, Tien jaar Trial and Error? De opbouw van het Oostenrijks bewind in de Zuidelijke Nederlanden (1716-1725) (diss. doc.), Gent, UGent, 2012 , p. 145).

34 Alexandre DuPILET, La Régence absolue: Philippe d'Orléans et la polysynodie, Seyssel, Champ Vallon, 2011 (Époques); Emmanuel Le Roy LadurIE, Saint-Simon ou le Système de la Cour, Paris, le grand livre du mois, 1998. 
declaration of renunciation to the French throne ${ }^{35}$. Consequently, Philip of Orléans' political fate depended on the Treaties of Utrecht ${ }^{36}$.

On the other side of the Channel, George I's position as King of Great Britain was guaranteed internally by the Act of Settlement. However, James III's supporters denied the legal validity of Parliament's chasing James II in 1688, which only intervened after an invasion by the Dutch ${ }^{37}$. Thus, George I needed an international back-up too, which could be found in the recognition of the Protestant Succession in Britain, as expressed in the Treaties of Rijswijk and Utrecht ${ }^{38}$. George I was King of Great Britain, but a German Elector as well. As Duke of Hanover, he saw his interests compromised in Northern Germany. Emperor Charles VI delayed the issuing of letters of investiture for the acquisition of the duchies of Bremen and Verden. Moreover, in the Great Northern War, a conflict dragging on since $1700^{39}$, George had fought Sweden, but feared an alliance between Russia, Sweden, Spain and Pretender James III. When Czar Peter the Great (1672-1725) stationed 40000 troops in the Duchy of Mecklenburg, bordering on Hanover ${ }^{40}$, Dubois' offer of an alliance with France was finally accepted. George I and his principal minister James Stanhope (1673-1721) opted for France in November 171641. This fundamentally altered the whole of European politics, "North" and "South" combined.

The Anglo-French alliance, elaborated in the Summer and Fall of 1717, obtained Dutch accession, in the so-called Triple Alliance of 4 January 171742. The Dutch Republic guaranteed Britain's and France's choice to discard constitutionally legitimate heirs to the throne ${ }^{43}$. This new combination tied three previously unlikely partners together and left the Emperor aloof of three big powers neighbouring his possessions in the Southern Netherlands. When Philip V of Spain invaded Charles VI's island Sardinia, barely six months later, the Dutch steered an independent course and let the multilateral intervention to France and Britain. Dutch absence in the so-called Quadruple Alliance ${ }^{44}$ (where the Republic's place was left open, to be never filled) implied Dutch absence at the Congress of Cambrai (1722-1725), designed to settle the quarrel between Philip V and Charles VI.

35 Philip V had to renounce his rights before signing the Peace Treaty at Utrecht, text : Declaration of Philip V, Madrid, 3 July 1712, CUD, vIII/1, nr. CXXXI, 304. Alfred BAUDRILLART, "Examen des droits de Philippe V et de ses descendants au trône de France, en dehors des renonciations d'Utrecht", in Revue d'Histoire Diplomatique III (1889), p. 161-191 \& 354-384; ID., Philippe V et la cour de France: d'après des documents inédits tirés des archives espagnoles de Simancas et d'Alcala de Hénarès et des Archives du Ministère des affaires étrangères à Paris, Paris, Didot, 1890, 5 v.

36 Which provided his own Bourbon-Orléans branch with a remote possibility to claim the crown if Louis XV came to die without male issue (See Émile BOURGEOIS, La Diplomatie secrète au XVIIIe siècle, Paris, Armand Collin, 1909, I).

${ }^{37}$ Jonathan IsRAEL, The Dutch Republic. Its Rise, Greatness and Fall 1477-1806, Oxford, Clarendon Press, $1988^{2}$, CLI, p. 340.

38 Art. IV, Treaty of Peace between Louis XIV and Queen Anne, Utrecht, 11 April 1713, CUD, VIII/1, nr.

39 Erik Schnakenbourg, La France, le Nord et l'Europe au début du XVIIIe siècle, Paris, Champion, 2008 (Bibliothèque d'histoire moderne et contemporaine; 26).

${ }^{40}$ Manfred HellmanN, "Die Friedensschlüsse von Nystad (1721) und Teschen (1779) als Etappen des Vordringens Russlands nach Europa”, in Historisches Jabrbuch XCVII/XCVIII (1978), p. 270-288.

${ }^{41}$ Robert Walpole and Charles Townshend quit cabinet (the so-called "Whig Split"), but would continue a pro-French and anti-Imperial policy after Stanhope's decease allowed them to return to government in 1721 (John Joseph Murray, George I, the Baltic and the Whig Split of 1717. A Study in Diplomacy and Propaganda, London, Routledge \& Kegan Paul, 1969). The link between Jacobitism and foreign policy was further exploited by Stanhope, when the Swedish ambassador Gyllenborg was arrested (29 January 1717) on rumours of a plot threatening the Protestant Succession (DHONDT, Balance of Power, p. 72-78).

42 Treaty between Louis XV, George I and the States-General, The Hague, 4 January 1717, CUD VIII/1, nr. CLXXXVI, p. 484-488.

43 "Contre les partisans de la légitimé royale, le Régent passait un contrat avec les partisans du droit des peuples, avec les pays républicains”, BOURGEOIS, Diplomatie secrète, p. 173-174.

44 Treaty between Charles VI, Louis XV and George I, London, 2 August 1718, CUD VIII/2, nr. CCII, p. 531 541 
Consequently, whereas the Maritime Powers had been united in 1715 for the status of the Southern Netherlands, Britain went with France, as it had done before at the end of 1711, when separate FrancoBritish peace preliminaries showed the blueprint for the end of the War of the Spanish Succession ${ }^{45}$. A major element of tension in European international relations during Louis XIV's reign, the opposition between France and the Protestant Maritime Powers ${ }^{46}$, was relegated to the background. The application, interpretation and amending of the Peace of Utrecht united French and British diplomats ${ }^{47}$.

The consequences for the status of the Austrian Netherlands were considerable. On the basis of the abovementioned diplomatic movements, Charles VI obtained leverage on Britain and the Dutch Republic. In order to solve a problem at the European table, French involvement was indispensable. As long as Charles remained in a deadlock with Philip V of Spain, France and Britain could make any concession towards the Emperor conditional on his acceptance of the broader diplomatic framework imposed by the Peace of Utrecht. Once Charles and Philip would have solved their bilateral issues, they could try to challenge the new consensus between the main power at sea, Britain, and the main land power, France. While the main powers in Europe were rapidly changing their positions, trade in Ostend continued: on 30 August 1716, the Saint-Mathieu returned from Surate on the Indian West coast and generated enormous profits for its initial investors.

\section{Bilateral restraints: self-interest and opportunistic argumentation}

Le Commerce est naturellement jaloux, \& interessé. Comme son objet prochain, \& immediat est le gain, \& qu'on ne l'entreprend jamais, que pour gagner, c'est aussi toujours de ce coté là que se tourne la principale attention de ceux, qui s'en mêlent.

Du Mont, La Vérité, 35-3648

The Dutch Republic and its East India Company $\left(\mathrm{VOC}^{49}\right)$ questioned the legitimacy of the Ostend trade, and were eventually prepared to use force to compel Charles VI ${ }^{50}$. Already on 27 April 1719, the Marquis de Prié was confiscated at Cape Lahou, forty miles ahead of the Dutch fortress Laxim and thus well off the African coast ${ }^{51}$. On 4 July of the same year, sales of tea shipped to Ostend from Canton by the Prince Eugène alone amounted to a million florins. Determined not to let the seizure of the Marquis de Prié pass, captain De Winter took the Dutch yacht Commany, filled with African elephant teeth, on 23 October 1719

45 Preliminaries of Peace between Louis XIV and Queen Anne, London, 8 October 1711, CUD, nr. CXIX, VIII/1, p. 281. BELY, Espions et ambassadeurs au temps de Louis XIV, Paris, Fayard, 1990, p. 576-595; DHONDT, "L'équilibre européen et la Succession d'Espagne. L'épisode révélateur des négociations de Nicolas Mesnager en Hollande, 1707-1708", in Véronique DemarS-Sion et al. (dir.), Diplomates et Diplomatie. Actes des Journées Internationales tenues à Péronne du 22 an 23 mai 2009, Lille, Université Lille 2-Centre d'histoire judiciaire, 2013 (Société d'Histoire du Droit et des Institutions des Pays Flamands, Picards et Wallons), p. 97-112.

${ }^{46}$ Charles-Édouard LEVILLAIN, Vaincre Louis XIV: Angleterre, Hollande, France, histoire d'une relation triangulaire 1665-1668, Seyssel, Champ Vallon, 2010 (Époques).

${ }^{47}$ DHONDT, "Legal Discourse between Integration and Disintegration: The Case of the Peaceful Succession Struggles, 1713-1739”, in Janwillem OOSTERHUIS \& Emanuel VAN DONGEN (eds.), European Traditions: Integration or Disintegration?, Nijmegen, Wolf Legal Publishers, 2013, p. 159-174.

${ }^{48}$ Du MONT DE CARELS-KROON, La Vérité du fait, du droit, et de l'intérêt de tout ce qui concerne le commerce des Indes établi aux Païs Bas Autrichiens par octroi de Sa Majesté Imper. Et Catholique, s.l., s.n., 1726, p. 35-36.

49 On its legal structure, Matthijs DE JONGH, Tussen societas en universitas. De beursvennootschap en haar aandeelhouders in historisch perspectief (diss. doc), Rotterdam, Erasmus University, 2014, p. 59-131.

${ }^{50}$ Victor Enthoven, "Dan maar oorlog! De reactie van de Republiek op de Oostendse Compagnie, 1715-1732”, in Parmentier (ed.), Noord-Zuid in Oost-Indisch Perspectief, Zutphen: Walburg Pers, 2005, p. 131-148. The threat to use force was not only directed at the Emperor, but at potential investors as well. E.g. on 9 August 1723, a thousand copies of the VOC's memorandum was printed and distributed in Antwerp, were substantial capital had been raised for the Company (Michel HuISMAN, La Belgique commerciale sous l'empereur Charles VI : la Compagnie d'Ostende: étude historique de politique commerciale et coloniale, Bruxelles, Lamertin, 1902, p. 240).

${ }^{51}$ Du MONT, La Vérité du fait, op. cit., p. 22. 
off the Belgian coast, an action approved by the Council of State in Brussels ${ }^{52}$. Southern Netherlanders founded trade posts on the Coromandel coast and in Bangladesh. Emperor Charles VI formalised the enterprise, now operating as a joint stock corporation, granting its formal permission on 19 December 172253. Few months later, on 5 April 1723, the Dutch resident Pesters presented memoranda drafted by the States-General and the VOC (drafted by their avocat, de la Bassecourt) to the Marquis of Prié54. Simultaneously, Hamel Bruynincx (1661-1738), envoy of the Republic in Vienna, presented the same texts to Charles VI ${ }^{55}$. In essence, Dutch argumentation constituted a 180 degree turn away from Grotius' famous seventeenth-century stand for free navigation on the high seas in De Iure Praeda ${ }^{56}$. Whereas the famous jurist had argued that neither the Kings of Spain and Portugal ${ }^{57}$, nor the King of England, could claim the exclusion of the Dutch from the ranks of the seafaring nations, the interests of the Republic were better served by the opposite point of view, a century later.

\section{The Dutch East India Company and her legal weapons}

Two more substantial, separately published treatises represent the Dutch vituperations against Ostend. Jean Barbeyrac (1674-1744) ${ }^{58}$, professor of Public Law at Groningen, and Abraham Westerveen ( $\left.{ }^{\circ} 1647\right)$, former lawyer for the East India Company, attacked the Imperial Company with arguments from treaty law ${ }^{59}$. The Peace Treaty of Munster between Spain and the Dutch Republic, concluded in 1648, constituted the core of Dutch pamphlets. Philip IV, at that time King of Spain, Duke of Brabant, Count of Flanders, Lord of Malines and sovereign in the remaining provinces left to him by Charles V, Philip II (1527-1598) and Philip III (1578-1621), conceded to the Seven Provinces of the North on multiple points. First, final recognition of the statehood assumed by the former Spanish provinces. Second, recognition of their colonial and commercial expansion. Finally, exclusion of his own subjects from trade in the Indies.

It was crucial for the VOC to prove that these limitations had been transmitted from Philip IV and his successor Charles II to Charles VI, who had been recognised as sovereign in the Southern Netherlands by Britain and the Dutch Republic in the Treaty of the Grand Alliance ${ }^{60}$. This document constituted the core

52 Marquis de Prié to Charles VI, Report on his administration of the Southern Netherlands, 16 April 1725, published in Louis Prosper GACHARD (ed.), Collection de documents inédits concernant l'bistoire de la Belgique, Bruxelles, Louis Hauman \& Cie, 1835, III, p. 500-502 and p. 504-512.

${ }^{53}$ Lettres Patentes d'Octroi, accordées par l'Empereur Charles VI. pour le terme de trente années à la Compagnie des Indes dans les Païs-Bas Autrichiens, Vienna, 19 December 1722, CUD, VIII/2, nr. XIX, p. 44-51. The formalisation of the Ostend enterprise should not obscure the abovementioned private initiatives from Ostend or "Flemish" participation in e.g. French smuggling trade with the East Indies (DEGRYSE, "De vrienden van 'Mijnheer Crozat' of de Zuid-Nederlandse betrokkenheid bij de Franse handel op de Stille Zuidzee (1710-1719)", in PARMENTIER \& S. SPANOGHE (eds.), Orbis in Orbem. Liber Amicorum John Everaert, Gent, Academia Press, 2001, p. 157-170.

${ }^{54}$ E.g. Memorandum presented by Ernst Pesters, resident of the States-General in Brussels (1717-1728) to the Marquis of Prié, Brussels, 5 April 1723, Du Mont, La Vérité du fait, op. cit., p. 85-87.

${ }_{55}^{5}$ Du MONT, La Vérité du fait, op. cit., p. 22.

56 Robert FEenstra \& Jeroen VerVLIET (eds.), Hugo Grotius' Mare Liberum: 1609-2009, Leiden: Martinus Nijhoff, 2009.

57 Seraphim DE FREITAS, Freitas contre Grotius sur la question de la liberté des mers. Justification de la domination portugaise en Asie (trad. Alfred GuICHON DE GRANDPONT), Paris, Gaillard \& Cie, 1893.

58 Not "Barbeyron" (Dumont, L'épopée de la Compagnie, p. 197). Barbeyrac had been active as a classics teacher in Berlin, where he translated Pufendorf's De Jure Naturae et Gentium (1706) to French. In Lausanne, Barbeyrac taught droit et histoire from 1710 to 1717, to be called to Groningen as professor ordinarius in droit public et particulier. In 1724, Barbeyrac completed his translation of Grotius' magnum opus De Iure Belli ac Pacis Libri Tres, following a critical edition in 1720. Barbeyrac's translations were of paramount importance for diplomatic practice, since his French translations were more accessible than the Latin originals.

59 Abraham WesterveEn, Vertoog van het regt, Dat de Vereenigde Nederlandsche Oost-Indische Maatschappye Heeft op de Vaart en Koophandel Naar Oost-Indiën; Tegen de Inwoonders van de Spaanse, nu de Oostenrykse Nederlanden, Amsterdam, Johannes de Ruyter, 1722. See as well, in a shorter version, CUD, VIII/2, nr. XXI, p. 78-80.

60 Tractatus Foederis inter Sacram Caesaream Majestatem Leopolum I. Regiam Majestatem Britanniae Wilhelmum III. Necnon Praepotentes Ordines Generales Foederatarum Belgii Provinciarum, ad procuandum Suae Caesareae Majestati ratione praetensionis suae in Successionem Hispanicam satisfactionem aequam \& rationi 
of the grand coalition against Louis XIV and his grandson Philip V. Charles of Habsburg, at that time Archduke and younger brother to Archduke Joseph (1683-1711), King of the Romans (and thus his father's designated successor as Emperor), had been promised nothing more than a just and reasonable satisfaction in the Spanish Succession ${ }^{61}$. This was even more true when Charles was elected Emperor himself, after Joseph's unexpected decease in April 1711. In the Grand Alliance, the Southern Netherlands had been identified as the prime bulwark against future French aggression (obex et repagulum, vulgo Barrière). The formal recognition of Charles VI's sovereignty happened at the Treaties of Utrecht (11 April 1713, France/Britain) and Rastatt (6 March 1714, France/Emperor), stating that the Southern Netherlands would be transferred to the Emperor in the same status they had belonged to Charles II of Spain (tels que feu le Roy d'Espagne Charles II. les a possedés ou dû posséder, conformément au Traité de Ryswické(2). The Barrier Treaty confirmed -in a general way- all relevant trade clauses of the Treaty of Munster ${ }^{63}$. If the exclusion of all Spanish subjects included inhabitants of the Spanish Netherlands, this limitation had to be continued under Austrian rule.

Once this bilateral and conventional argument was accepted, Barbeyrac and Westerveen needed to buttress it against challenges stemming from natural law. Didn't the Digest state that the navigation on the high seas, necessary means of communication between nations, was a natural right ${ }^{64}$ ? Even more, Hugo Grotius had famously leaned on this statement to defend Dutch pretentions against Spain and Portugal, a century earlier ${ }^{65}$. The VOC's advocates turned to the ruse of mare natura liberum, pactis clausum 66 ("the sea is free by nature, but can be closed by treaties"). Although navigation on the high seas pertained to all nations, they could renounce this right merae facultatis in a convention. Renunciations were coupled with reciprocal advantages, and would not have been contracted without cause. However, if one assumed the opposite position (namely that free navigation on the high seas constituted a peremptory norm of natural law, overriding contrary treaties concluded between states), another hot issue in North/South-relations resurfaced. The Treaty of Munster had closed (art. XIV) the navigation of the Scheldt and other embouchures on the North Sea, which reflected the military state of affairs from early in the Dutch Revolt ${ }^{67}$. Neny ${ }^{68}$, who defended the Southern Netherlands' point of view, had put this at the same level as

convenientem, uti \& ad adipiscendum pro Rege Magnae Britanniae \& Dominis Ordinibus Generalibus securitatem particularem \& sufficientem, The Hague, 7 September 1701, CUD, VIII/1, nr. XIII, p. 89-91.

${ }^{61}$ Du Mont, La Vérité du fait, op. cit., p. 49 ; See DHONDT, "Entre droit privé et droit international : la succession d'Espagne aux XVIIe et XVIIIe siècles", Cabiers du centre de recherches en histoire du droit et des institutions: Histoire(s) du droit, dir. Marie MOULART et Emmanuël FALZONE. nº 35-36 (2011), p. 61-102.

62 Art. XIX Treaty of Rastatt; BARBEYRAC, Défense du droit, op. cit., p. 13; art. I, Barrier Treaty; WESTERVEEN, Vertoog van het regt, op. cit., p. 8. Janvier 1648

${ }^{63}$ Art. XXVI, Barrier Treaty: sur le pié établi, \& de la maniére portée par les Articles du Traité fait à Munster le 30.

${ }^{64}$ VATTEL, Le Droit des Gens, op. cit., Book II, \132: La propriété n’a pu ôter aux Nations le droit général de parcourir la terre, pour communiquer ensemble, pour commercer entr'elles, \& pour d'autres justes raisons.

${ }^{65}$ Monica Brito VieiriA, "Mare Liberum vs. Mare Clausum: Grotius, Freitas, and Selden's Debate on Dominion over the Seas", Journal of the History of Ideas LXIV (2003), No. 3 (Jul), p. 361-377.

Water, 1728

66 Theodor GRAVER, Dissertatio juridica inauguralis, de mari natura libero, pactis clauso, Utrecht, Willem vande

${ }^{67}$ Huisman, La Belgique commerciale, p. 5.

${ }^{68}$ Patrice DE NENY, Demonstration de l'injuste et chimerique pretention que les Directeurs de la Compagnie des Indes en Hollande forment afin de faire revoquer, ou du moins rendre inutile l'Octroy que Sa Majesté Imperiale \& Catholique a accordé à ses Sujets des Païs-bas Autrichiens pour l'Etablissement d'une Compagnie de Commerce \& de Navigation aux Indes Orientales \& Occidentales, s.l., s.d., 1724. Patrice de Neny, originally Patrick Mac Neny (1675-1745), studied law at the University of Leuven (1691-1702). An avocat at the Council of Brabant (1703), he climbed to the rank of councillor in the Council of Finance (1713) at the end of the War of the Spanish Succession. At the 1718-1719 negotiations on the amendment of the Barrier Treaty, Neny was sent to The Hague. In 1724, Eugene of Savoy, governor-general of the Southern Netherlands, appointed him as Secretary of State and War, a position which he occupied until his death. Neny was the main person of confidence for the Marquis of Prié (1658-1726), minister plenipotentiary of Charles VI in Brussels. See Bruno BernARD, "Patrice Mac Neny (1676-1745) Secrétaire d'État et de Guerre", Études sur le XVIIIe siècle XII (1985) (Hervé HASQUIN \& Roland MORTIER (eds.), Une famille de hauts fonctionnaires : les Neny), Bruxelles, 
the supposed renunciation of the Southern Netherlanders' right to sail to the Indies: un entier renversement des Loix du Droit des Gens, parce qu'on y prive toutes les Nations du Monde de la Liberté Naturelle que Dieu Leur a donnée, par l'Interdiction qu'on leur a faite d'entrer dans les Provinces de Brabant, \& de Flandres avec Leurs propres Vaisseaux \& Marchandises ${ }^{6}$.

Barbeyrac's Défense du droit de la Compagnie Hollandoise des Indes Orientales appeared on 17 January 1725. By then, the Congress of Cambrai had been busy for almost a year. The treatise was framed as a response to Neny. Just as with his French translations of Pufendorf $\mathrm{f}^{70}$ and Grotius ${ }^{71}$, Barbeyrac reached a more substantial audience in French-speaking Europe than with a treatise in Latin or Dutch, wherein Westerveen published his defence of the $\mathrm{VOC}^{72}$. Neny, by contrast, had written in French and thus potentially harmed the Dutch case by reaching out wider. Like Westerveen in a second version of his Dissertatio, a year earlier ${ }^{73}$, Barbeyrac offered to correct Neny's errors, d'éplucher tout, \& de ne rien laisser passer, qui ne fut une répétition toute pure. If the Dutch based their defence on the 1648 Treaty of Munster, chronological coincidence seemed to be on the Austrian side. Grotius' major works coincided with important evolutions in the Eighty and Thirty Years' War, the conflicts that ended in 1648. If Grotius stated in De Iure Praedae (XII, I-21674) that all peoples equally enjoyed the right to visit other nations and carry on their trade, how could this argument of natural law be cast aside by the positive law of nations?

As a professor of public law at Groningen and a recognised expert in the law of nations (on the basis of his translations, as well as the edition of treaties from Antiquity), Barbeyrac claimed the objectivity of his method equalled that of other types of scholarly activity ${ }^{75}$. In spite of Barbeyrac's reputation as a systematic thinker, he composed a hodgepodge of diverse arguments drawn from any possible source. For instance, he took the long delay between the origin of times and 1722 as a sign that the inhabitants of the Southern Netherlands forfeited their right to navigation, or implicitly recognized they were under a limitation based on the Treaty of Munster ${ }^{76}$. Barbeyrac, in his defence of the Republic's exclusive rights, even quoted Zypaeus, who defended the claims of the King of Spain on maritime dominium in the seventeenth century: Mare non liberum, ut voluit Grotius, sed potius Iberum hodie sit censendum ${ }^{77}$.

Primary natural law $v$. voluntary law of nations

ULB, 1985, p. 7-78 ; Jacques LEFÈvRE, "NENY (Patrice DE)”, Biographie Nationale de Belgique, I (fasc. 1), Bruxelles, Bruylandt, 1956, p. 406-407 ; VAN GELDER, Tien jaar Trial and Error ?, p. 137-138 and 299-303.

${ }^{69} \mathrm{NENY}$, Démonstration de l'injuste et chimerique pretention, op. cit., p. 42.

70 Samuel VON PUFENDORF, Les devoirs de l'homme, et du citoien, tels qu'ils lui sont prescrits par la loi naturelle (transl. J. Barbeyrac), Amsterdam, Pierre de Coup, $1715^{3}$.

${ }^{71}$ Hugo GRoTIUS, Le droit de la guerre et de la paix (trad. BARBEYRAC), Amsterdam, De Coup, 1724.

72 Abraham WesterveEn, Dissertatio de Jure, Quod Competit Societati Privilegiata Faderati Belgii Ad Navigationem \& Commercia Indiarum Orientalium, Adversus Incolas Belgii Hispanici-bodie-Austriaci, Amsterdam, Wetstein, 1722; BARBEYRAC, Défense du droit, op. cit., Avertissement.

73 WesterveEn, A Second Dissertation Concerning the Right of the Dutch East-India Company To the Trade and Navigation of the East-Indies, Against the Inhabitants of the Spanish, now Austrian Netherlands, In Answer to the objections of Mr. P. Mac Neny, Counseor \& Proc. Fiscal, to His Imperial \& Catholick Majesty, The Hague, Johnson, 1724; Dutch version: Europische Mercurius XXXV (1724), p. 212-248.

${ }^{74}$ Hoc igitur jus ad cunctas gentes aequaliter pertinet: quod clarissimi jurisconsulti eousque producunt, ut negent ullam rempublicam aut Principem probibere in universum posse, quominus alii ad subditos suos accedant et cum illis negotientur.

75 BARBEYRAc, Défense du droit, op. cit., Avertissement: J'ai examiné les matiéres non seulement avec beaucoup d'attention, mais encore avec la méme indifférence \&o la même impartialité, que si j'avois ề à discuter un point de l'Histoire Ancienne, \& à chercher, par exemple, le vrai sens d'un Traité fait entre Philippe de Macedoine, \& les Athéniens.

76 Barbeyrac, Défense du droit, op. cit., p. 2. VATTEL (Le Droit des Gens, op. cit., Book I, \$285) refuted this : although any state can decide not to engage in commerce or renounce it on a contractual basis, this implies an act of will. In absence of this, prescription (i.e. the mere passage of time) cannot provoke the loss of this faculty. Moreover, Du Mont argued that, while under Spanish domination, the Southern Netherlands were deprived of the exercise of their legal capacities: Non valenti ageree non currit praescriptio (DU MONT, La Vérité du fait, op. cit., p. 33).

${ }^{77}$ Franciscus ZYPAEUS, Notitia iuris belgici, Antwerpen, Verdussen, 1635, p. 284. 
According to Barbeyrac, the VOC's right to trade and navigate was grounded on Priviléges \& Traitez solennels qui les lui ont assurez d'une maniére irrevocable par rapport aux Habitans des Païs-Bas Autrichiens ${ }^{78}$ : by not questioning the VOC's right to sail to the Indies and conversely abstaining from doing the same, Philip IV's and Charles II's subjects had both forfeited their own right ${ }^{79}$ and confirmed that of the Dutch. Westerveen supported this position leaning on Baldus' commentary on the Digest, according to whom distinctions between states could be applied at sea as well as on land ${ }^{80}$, on the Church Father Ambrosius or John Selden (whose theses had been opposed to those of Grotius in the seventeenth century81). Moreover, Spanish state practice to exclude foreign nations from direct commerce with Spain's colonies in the Indies provided the world with clear boundaries, which were an essential precondition to international stability ${ }^{82}$. Finally, the right thus accorded to the Dutch by treaty did not necessarily amount to full dominium. In analogy with civil law, real property rights of use or enjoyment, including the right to exclude third party-access, could be granted to states, distinct from property ${ }^{83}$.

Barbeyrac tackled the issue of free navigation head-on: Le vaste Océan n'est à personne: d'accord [...] Mais qu'estce qui empêche que deux Princes ou deux Peuples conviennent entr'eux, que l'un ne mettra point de Vaisseaux en mer, ou qu'il n'en envoiera que jusqu'à un certain endroit de l'Océan, ou de quelque autre Mer moins vaste, ou qu'il n'ira point commercer en tel ou tel endroit ${ }^{44}$ ? In other words, Barbeyrac distinguished between a hard right to navigate, and a (soft) possibility to exercise that right, the latter leading to a reliable promise to another sovereign, whose consent is needed to recover the initially forfeited right. Mare liberum is thus turned into a disposition of supplementary law: mare liberum... pactis clausum. Barbeyrac found a legitimacy for renunciation in the general reciprocity between nations: we forfeit our right to navigation "en comptant sur ce que les autres veulent à leur tour nous ceder des leurs ${ }^{85}$." In the "Belgian" case, Philip IV acted on behalf of his territories by the North Sea, and rightly so, as their legitimate sovereign. Philip ratified the treaty as King of Castille, Duke of Brabant and Count of Flanders, obliging all of his vassals and subjects alike ${ }^{86}$. In case his subjects would not have consented to the imposition of this limitation, they had to make this known within a reasonable lapse of time ${ }^{87}$.

Westerveen distinguished between situations leading to an opposable claim on international trade. The Dutch trading companies had acquired their exclusive right to sail to the part of the Indies they controlled at the Treaty of Munster. This Peace Treaty ended the Eighty Years' War. Consequently, the Dutch Republic had obtained an exclusive right, following the Spanish renunciation on behalf of Philip IV's citizens, on the basis of a right of conquest. The outcome of an armed conflict could put the rules of the initial state of nature, wherein navigation on the high seas was free, aside. Just as the state of nature between individuals did not know appropriation yet, the status of the high seas as the common heritage of men was a merely transitory one. The Dutch Republic could thus acquire the exclusive right to sail to the

78 BARBEYRAC, Défense du droit, op. cit., p. 11.

79 Après quoi, il ne sauroit légitimement se plaindre, de ce qu'il n'a plus la liberté de disposer à sa fantaisie d'une chose qui lui appartenoit (sic) à l'exclusion de tous les autres. A plus forte raison, auroit-on mauvaise grâce que de vouloir revenir d'une Rénonciation, qui a pour objet des choses auxquelles auparavant on n'avait qu'un droit commun (BARBEYRAC, Défense, p. 4).

80 Ad L. I. Dig. De Rer. Div.

81 WesterveEN, Vertoog van het regt, op. cit., p. 3; Andrea WeInDL, "Grotius's Mare Liberum in the Political Practice of Early-Modern Europe”, Grotiana XXX (2009), No. 1, p. 131-151.

82 WeSTERVEEN, Vertoog van het regt, op. cit., p. 4.

${ }^{83}$ In the same sense, Grotius provided for a right of exclusion, distinct from full appropriation by the VOC (Marti KoskenNIEMI, "International Law and the Emergence of Mercantile Capitalism: Grotius to Smith", in Pierre-Marie DuPUY \& Vincent CHETAIL (eds.), The Roots of International Law - Les fondements du droit international. Liber amicorum Peter Haggenmacher, Leiden, Martinus Nijhoff, 2014 (Legal History Library; 11/Studies in the History of International Law; 5; ed. Randall LESAFFER), p. 21.

${ }^{84}$ BARBEYRAC, Défense du droit, op. cit., p. 4.

${ }^{85}$ Ibid.

86 WESTERVEEN, Vertoog van het regt., op. cit., p. 22.

${ }^{87}$ BARBEYRAC, Défense du droit, op. cit., p. 5. 
Indies for the VOC. Conversely, the Ostend Company could not unilaterally claim the same without right of conquest or sovereign (Dutch) consent concerning the King of Spain's renunciation of his subjects' right ${ }^{88}$. Erecting trade posts, fortifications or settlements on the Dutch's East Asian shores, unilaterally claiming part of the VOC's profit without consent, equalled restarting the military conflict between the States-General and the sovereign of the Southern Netherlands ${ }^{89}$.

\section{Positive law}

According to Barbeyrac, the Southern Netherlands' treaty-based exclusion from navigation did not date back to 1648 or 1598 , but to 1609 , at the time of the Twelve Years' Truce between Philip III, the Archdukes Albert of Austria (1559-1621) and the Infant Isabella of Spain (1566-1633), on the one hand and the Dutch Republic, on the other hand ${ }^{90}$. Initially, the treaty restored trade between North and South. Yet, this is immediately limited to the "Royaumes, Provinces, Pays \& Seigneuries qu'il [Philip III] tient \& possede en Europe ${ }^{91}$ ". Trade outside of Europe was subject to royal approval. Barbeyrac and Westerveen"2, however, read this as including the VOC's (national) privilege of 1602, and applying only to inhabitants over whom the King of Spain still exerted control. In their view, in 1621, at the creation of the Dutch West India Company (WIC), the Southern Netherlands did not utter any protest. At the conclusion of the Truce, a declaration interpreting article IV as including Spanish territories outside Europe as well, had been accepted by Philip III's delegates ${ }^{93}$.

The Treaty of Munster brought Spanish recognition for both VOC and the WIC ${ }^{94}$. Philip IV renounced to all establishments in both Indies occupied by any of the Dutch companies, and extended their privileges to all Spanish possessions within Europe ${ }^{95}$. However, article V of the Treaty of Munster created difficulties for Barbeyrac. The Spanish negotiators had opted for the term Castillans or Espagnols to designate Philip IV's subjects. Preparatory meetings and memoranda from both companies used the terms indistinctly for all subjects, argued both Westerveen ${ }^{96}$ and Barbeyrac: article VI relating to the West Indies mentioned all subjects of Philip's Kingdoms and Provinces and should be read as an elaboration of the preceding $\operatorname{article~}^{97}$.

How could Philip have meant to exclude his non-Castillian subjects? The Dutch Republic would have lost its advantage in contracting such a restricted commercial renunciation clause. Contracts ought to be interpreted according to party intent, and -following Cicero- the requirements of good faith push to

88 WESTERVEEN, Vertoog van het regt, op.cit., p. 14: zodanige verschillen moeten afgedaan werden, na 't eerste Volker-regt, volgens welk. by na alles gemeen was, daar nogtans geleerden en ongeleerden beyde bekend is, dat door 't regt, 't geen nu plaats beeft, en by alle volkeren even zeer werd bewaard, veele dingen onderscheyden ayn, die in ouder tyd niet onderscheyden waaren.

${ }^{89}$ WESTERVEEN, Vertoog van het regt, op.cit, p. 14, referring to the Dutch East Indies trade as the main reason for the end of the Twelve Years' Truce.

${ }^{90}$ García García (ed.), Tiempo de Paces. La Pax Hispanica y la Tregua de los Doce Años, Madrid, Fundación Carlos de Amberes, 2010.

${ }^{91}$ BARBEYRAC, Défense du droit, op. cit., p. 7.

92 WesterveEN, Vertoog van het regt, op.cit., p. 6.

${ }^{93}$ Protest by the Deputies of the States-General of the United Provinces of the Netherlands, Antwerp, 31 March 1609, published in Du MONT, La Vérité du fait, op. cit., p. 80: les dits Sieurs Roy Tres-Chrestien, e de la Grande Bretagne [mediators for the truce] ci devant priés de la part des Estats de se vouloir rendre garants de l'observation dudit Commerce comme promis \& accordé par les dits articles aussi valablement que si le mot des Indes y estoit exprimé; Declaration by the King of Spain and the Archduke's Deputies in favour of the States General of the United Provinces of the Netherlands, Antwerp, 9 April 1609, Du MONT, La Vérité du fait, op. cit., p. 81. See as well Treaty of Guaranty concluded between Henry IV of France and James I of England, The Hague, 7 June 1609, Du MONT, La Vérité du fait, op. cit., p. 82-83.

${ }^{44}$ The WIC also published a memorandum against the Ostend Company, CUD, VIII /2, nr. XXIV, p. 78.

95 BARBEYRAC, Défense du droit, op. cit., p. 9.

${ }^{96}$ In line with the VOC's remonstrances to the States General, The Hague, 1723, Du MONT, La Vérité du fait, op. cit., p. 87-92.

${ }^{97}$ WESTERVEEN, Vertoog van het regt, op.cit., p. 22. 
recognize dubious words as creating obligations, rather than as discharging debtors from what is due to their creditor ${ }^{98}$. Eliminating all non-Castillian subjects of Philip IV would equal the exclusion of the inhabitants of the conquered parts of North Brabant and Flanders (Generaliteitslanden) on the Dutch side ${ }^{99}$. Taken together with Philip III's restricted royal authorisation to his Castillian subjects to navigate and trade ${ }^{100}$, the inhabitants of the Southern Netherlands should be seen as excluded from participation in it. At the end of the sixteenth century, the Act of Cession (6 May 1598101) issued by Philip II to confer sovereignty over the Southern Netherlands to his daughter Isabella and her husband, Archduke Albert of Austria, did contain an explicit interdiction in its eighth article ${ }^{102}$, which was effectively applied on an Antwerp vessel sailing to the East Indies in 1600103. Westerveen further pointed to the Bastiaan Brouwercase, where a subject of Philip IV had sailed to Batavia in 1653. The local Dutch court, the Hooge Raad der Nederlandsche Indiën, had used article $\mathrm{V}$ of the Treaty of Munster to forbid the activities of this Spanish merchant.

Imperial passports granted to individuals sending out vessels for the Ostend Company contained an interdiction clause, containing the African coasts, or other places où il n'est pas permis suivant les Traitez, aux Sujets de Sa Maj. Imper. \& Cath. de commercer. Following the VOC's argumentation, Barbeyrac launched the obvious rhertorical question: Quels sont donc ces Traiter, si ce n'est celui de Munster \& les derniers qui le confirment ${ }^{104}$ Charles VI denied being under any limitation concerning the navigation of the high seas, and at the same time- confirmed the existence of positive law-limitations! If looked closer at the Barrier Treaty, the instrument containing the precise conditions of the transfer to Charles VI, article XXII stated that the new sovereign would execute all obligations pending on Charles II, mainly concerning the military expenses paid by the Maritime Powers to chase the French and Spanish from the Southern Netherlands. Barbeyrac sees here an indication of the more general nature of Charles VI's accession to the inheritance of Charles II, referring back to the general rule in the law of nations, according to which sovereigns generate obligations for themselves and their successors as well ${ }^{105}$. The analogy with civil law was obvious, with reference to the VOC's initial memorandum: selon le Traité de Munster, mais aussi selon Droit par la nature même de la chose, sçavoir que celui, qui succede par Droit de Succession en la place du deffunt, est tenu, \& engage d'observer, \& d'executer tous les Traités \& engagemens, que le defunt à (sic) fait, \& contracté avec d'autres ${ }^{106}$. The more considerable the part received by the Emperor, the less likely he could be considered as a specific legatee. If, moreover, the Emperor was held answerable for the debts contracted by Charles II for the preservation of his part of the inheritance, it would be more likely to see the Austrian Habsburgs as general successors,

98 WESTERVEEN, Vertoog van het regt, op.cit., p. 25. Which is the opposite of the normal rules of interpretation, restricting dubious words against the drafter.

99 Since the Generaliteitslanden (Generality Lands; see ISRAEL, The Dutch Republic, op. cit., p. 297-300) did not form part of the seven provinces which seceded from the XVII Provinces, they were put under direct administration by the States-General in The Hague.

100 An impression reinforced by the existence of the Casa de Contratacion in Seville, which served as a mandatory hub for foreign merchants trading with the Spanish West Indies (HuISMAN, La Belgique Commerciale, op. cit., p. 12).

101 Georges MARTYN, “How 'sovereign' were the Southern Netherlands under the Archdukes?” in LESAFfer (ed.), The Twelve Years Truce (1609-1621), Leiden, Martinus Nijhoff, 2014 (Studies in the History of International Law; 6), 2014, p. 196-209.

102 l'Infante \& Son Epoux ni aucun de Leurs Successeurs [...] ne feront aucun Commerce, trafic, ou contractation dans les Indes Orientales, ou Occidentales, ni n'enverront dans ces Païs-là aucune sorte de batimens sous quelque titre, nom, ou pretexte, que ce puisse être BARBEYRAC, Défense du droit, op. cit., p. 6; Du MONT, La Vérité du fait, op. cit., p. 89 ; WeSTERVEEN, Vertoog van het regt, op.cit., p. 7.

103 WESTERVEEN, Vertoog van het regt, op.cit., p. 8.

104 Barbeyrac, Défense du droit, op. cit., p. 108.

105 Memorandum VOC, Du MONT, La Vérité du fait, op. cit., p. 89. See as well G. Réal de Curban, La Science du gouvernement, t. 5: contenant le droit des gens, Qui traite les Ambassades; de la Guerre; des Traités; des Titres; des Prérogatives; des Prétentions, \& des Droits respectifs des Souverains, Paris, Les libraires associés, 1764, p. 620.

106 Memorandum VOC, Du MONT, La Vérité du fait, op. cit., p. 89. 
for benefits as well as burdens ${ }^{107}$. A sovereign bound to a treaty cannot lift his obligations arising from the latter by concluding another treaty contrary to it ${ }^{108}$.

From the British side, commercial competition -in this case for the East India Company- was not the only argument used ${ }^{109}$. The anonymous pamphlet The Importance of the Ostend-Company consider'd, which appeared in London in 1726, had a double argument ${ }^{110}$. On the one hand, the "Netherlands" or Austrian Netherlands had proven their commercial genius in the past. The renaissance of Antwerp, Malines, Brussels, Oudenarde, Courtrai, Ghent or Bruges ${ }^{111}$ would put an end to a mere transitory episode since the separation of the XVII Provinces. As formerly, those countries would become the "staple of Europe"112, popish merchants returning to the South from the Dutch Republic ${ }^{113}$. On the other hand, the decline of Dutch commerce would inevitably lead to the demise of the state as such ${ }^{114}$, leaving Britain alone to uphold the balance of power between Protestants and "Popery", more specifically the Catholic House of Austria ${ }^{115}$. Yet, the utility of religiously framed arguments was principally domestic. The diplomatic probability of a Catholic alliance between France, Spain and the Emperor was rather small, and remained so until the end of the War of the Polish Succession (1733-1738). French long-term geopolitical interest in dividing the Holy Roman Empire against the Habsburgs dominated.

In Defence of Flanders and the Emperor: Neny and Du Mont

Un droit de la nature \& des gens, anquel [les bons \& fideles Sujets] n'ont jamais renoncé.

Remonstrance by the States of Brabant on the Ostend Company, 23 March 1724116

Un droit primordial, qui autorise celle du Païs-Bas Autrichien à porter son Commerce aux Indes; $[\ldots]$ ce droit $[\ldots]$ n'est autre que le Droit Naturel, \& des Gens. Droit aussi ancien que le Monde, dont l'etendue embrasse tout le circuit du Globe terrestre, dont l'evidence est au dessus de toute prenve, \& la durée au de là de toute Prescription. C'est ce droit, qui fait le Premier Titre de nos Belges Autrichiens.

Jean Du Mont de Carels-kroon, La Vérite ${ }^{117}$

Neny's Demonstration de l'injuste et chimerique pretention ${ }^{118}$ was directed at the official VOC memorandum and its more elaborate version written by Westerveen. Neny positioned his pamphlet as restricted to the

${ }^{107}$ Interests on debts due to the Dutch Republic amounted to $9,35 \%$ on average of the annual budget of the Southern Netherlands (Van Gelder, Tien jaar Trial-and-Error, p. 146).

108 VATTEL, Le Droit des Gens, op. cit., Book II, \$165.

109 The Importance, 32. The British seized vessels as well, such as the Flandria off Bencoulen (British possession on Sumatra) on 9 August 1721 (Huisman, La Belgique commerciale, 195). British nationals operating from Ostend were seen as contravening to the East India Company's monopoly. From a legal point of view, the British supported the Dutch claims based on either the Barrier Treaty, to which they were party, and the general guarantee obligation in the bilateral treaty of 6 February 1716, or the constant practice since Munster to exclude the Southern Netherlanders from trade (Ibid., p. 231).

${ }^{110}$ See as well, Anonymous (William Pulteney), Mr. Forman's letter to the Right Honourable William Pulteney, Esw; Shewing how Pernicious, the Imperial Company of Commerce and Navigation, lately established in the Austrian Netherlands, is likely to prove to Great Britain, as well as to Holland, London, Buffey, 1725.

111 The Importance of the Ostend-Company consider'd, London, Say, 1726, p. 40.

112 Ibid., p. 39.

113 Ibid., p. 18, 19, 30.

114 For it is, I Think, impossible to assign any other reasons for the Riches, Power, and Grandeur of the Phoenicians, Carthaginians, Athenians and Rhodians of old; and of the Hand Towns, Genoa, Venice, the Province of Holland \&oc. at this Day. (Ibid., p. 38).

115 Ibid., p. 29.

116 Remonstrances by the States of the Duchy of Brabant to Charles VI, on the subject of the Ostend Company, Brussels, 23 March 1724, CUD, vIII/2, nr. XXVI, p. 80-82

117 Du MONT, La Vérité du fait, op. cit., p. 23. 
analysis of positive emanations of the law only, sans citations des Auteurs. The allegations of des Ecrivains mal appliquées had obscured the core of the dispute between North and South in such a way, that it had become unrecognisable. The Ostend Company's fate ought to be decided as un cas de fait, qui n'admet pas des interpretations arbitraries, ni subtilités du Barreau ${ }^{119}$. The reaction to Barbeyrac did not come from a Southern Netherlander, but from Jean Du Mont de Carels-Kroon ${ }^{120}$, Imperial historiographer and author of the most impressive treaty compilation of the age, the Corps Universel Diplomatique du Droit des Gens, later continued by Jean Rousset de Missy (1686-1762)121. Both Du Mont and Rousset were Huguenots ${ }^{122}$. Barbeyrac's treatise consisted of 285 paragraphs in 131 pages, but Du Mont remarked it scantly answered the arguments of Neny ${ }^{123}$. His own treatise tried to formulate the Company's case in a period of international tension between Charles VI and the Maritime Powers, which ended on 31 May 1727 with the Parisian Preliminaries of Peace, which signed the Company's death sentence ${ }^{124}$. Karel Filips Pattijn (16871773)'s treatise, which was distributed at the Congress of Soissons (1728-1730) following the Preliminaries, could not alter the participants' views, even those of the Imperial representatives, who had buried the Company ${ }^{125}$.

Free navigation on the high seas as a peremptory norm

No private person could claim ownership or any exclusive right on the high seas, its use and the freedom of trade, "des choses incontestablement inprescriptibles 126 ". Neny found it striking that other nations could carry on their activities where the Ostend Company was active, without provoking Dutch anger ${ }^{127}$. How could the VOC argue that it had acquired an exclusive right in those parts of the East Indies sailed by other nations ? Wasn't trade by its nature changeant \& muable and thus inappropriate to lead to the acquisition of full dominium 128 ? Even if the VOC and WIC existed for over a century, what did this change to the imprescriptible nature of free navigation on the high seas ${ }^{129}$ ? Next, according to Du Mont, couldn't the

118 Short version: Copy of the Memorandum presented to Prié on 22 October 1723 to serve as an answer to the Remonstrances of the VOC Directors, CUD, VIII/2, nr. XXVI, p. 82-85.

${ }^{119} \mathrm{NENY}$, Démonstration de l'injuste et chimerique pretention, op. cit., p. 3.

${ }^{120}$ HUISMAN, La Belgique commerciale, op. cit., p. 402.

${ }^{121}$ DHONDT, Balance of Power, op. cit., p. 18-26.

122 Georg Friedrich VON MARTENS, "Recherches sur la vie et les écrits de Jean du Mont baron de Carelscroon, redacteur du Corps Universel Diplomatique du droit des gens", in MARTENS, Supplément au recueil des principaux traités d'alliance, de paix, de trêve, de neutralité, de commerce, de limites, d'échange, etc., Göttingen, H. Dieterich, 1802, I, p. lxiv-xciv ; Graham C. GIBBS, "Some intellectual and political influences of the Huguenot Emigrés in the United Provinces c. 1680-1730", in Bijdragen en Mededelingen tot de Geschiedenis der Nederlanden - The Low Countries History Review XC (1975), No. 2, p. 255-287; ID., "The role of the Dutch Republic as the intellectual entrepot of Europe in the seventeenth and eighteenth centuries", ibid LXXXVI (1971), No. 3, p. 323-350; Linda \& Marsha FrEY, "DUMONT, JEAN, BARON DE CARLSCROON (1667-1726)", in L. \& M. FREY (eds.), The Treaties of the War of the Spanish Succession: an Historical and Critical Dictionary, Westport (Conn.), Greenwood Press, 1995, p. 139 ; IsRAEL, Radical Enlightenment: Philosophy and the Making of Modernity 1650-1750, Oxford, Oxford UP, 2001, p. 577 ; Stephan VEROSTA, "Droit international et droit interne chez Jean Dumont (1666-1727)", in Mélanges offerts à Henri Rolin, Paris, Pedone, 1964, p. 479-487.

${ }^{123}$ Du MONT, La Vérité du fait, op. cit.

124 Art. I, Preliminary Articles concluded between Charles VI and the Allies of Hanover, Paris, 31 May 1727, CUD VIII/2, nr. LVII, p. 146-148. Strictly interpreted, the article only foresaw a seven-year suspension of the Company's privilegium, vulgò (Octroy).

${ }^{125}$ L'Empereur n'a jamais prétendu tirer des thrésors des Païs-Bas autrichiens; et son intention n'est que de les garder pour le bien de la cause commune et de les conserver dans un état de défense, jugé nécessaire par le traité de Barrière, sans qu'il soit obligé, ny à surcharger pour cet effet ses fidels sujets, ny à employer les revenus de ses autres Païs héréditaires (Instructions for Kinsky and Fonseca, Austrian plenipotentiaries at the Soissons conference, February 1729, quoted in HuISMAN, La Belgique commerciale, op. cit., p. 446).

${ }^{126}$ NENY, Démonstration de l'injuste et chimerique pretention, op. cit., p. 21.

127 Les Flamands et les Brabançons ne font leur Commerce aux Indes, que dans les Lieux où toutes les autres Nations trafiquent librement, \& qu'il Leur est défendu par l'Octroy de S.M.I. \& C. de le faire ailleurs.

${ }^{128}$ NENY, Démonstration de l'injuste et chimerique pretention, op. cit., p. 21.

${ }^{129}$ Ibid., 21. 
Spanish and Portuguese, who had sailed the world seas for nearly a century without competition, have excluded the Dutch based on this argument ${ }^{130}$ ? What to think of French, British or Danish expeditions ${ }^{131}$ ? Moreover, if the Southern Netherlanders had abstained from sailing to the Indies, this was a consequence of the opulence which was theirs in the sixteenth century, before the Dutch Revolt: Mais pour peu qu'on fasse reflexion, à la richesse du Commerce dont ces Peuples étoient alors uniques Possesseurs, on comprendra aisement, qu'ils n'avoient pas sujet de porter envie à celui la. Ils regardoient les Castillans comme des Avanturiers, qui n'ayant que le Cape, \& l'Epée, ne faisoient pas mal d'aller chercher fortune en ces Regions sauvages \& eloignées 132.

\section{The Treaty of Munster did not concern La Nation Belgique133}

Neny tried to distinguish two aspects of the Spanish Habsburg rulers of the Netherlands. On the one hand, he saw them continuing the Burgundian heritage, on the other hand, they wore the crown of Spain. In 1648, Philip IV would have ruled over the Spanish Netherlands as George I did in 1714 over Hanover ${ }^{134}$. Consequently, treaties contracted into as head of the Burgundian territories, could not bind Spanish subjects and vice versa. Barbeyrac refuted this distinction. First, Charles V inherited Brabant and Flanders from his grandmother Mary of Burgundy, and explicitly detached the Southern Netherlands from the Holy Roman Empire at the Transaction of Augsburg ${ }^{135}$ (26 June 1548). Consequently, Spain and the XVII Provinces had always been tied together. Seeing a distinct succession by Charles VI, as Archduke in Austria, King of Bohemia, King of Hungary, King of Sardinia, Duke of Milan and the other "Austrian"

130 Du MONT, La Vérité du fait, op. cit., p. 13.
131 Ibid., p. 23.
132 Ibid., p. 18.
133 Ibid., p. 17.
134 NeNY, Démonstration de l'injuste et chimerique pretention, op. cit., p. 5.
135 The question was actually a matter of debate between Spain and the Austrian Habsburgs in the 17th century. The revenues in the Duchy of Brabant assigned to the contribution for the Imperial Chamber Court remained unpaid for several years, in spite of a condemnation by the Council of Brabant. Although the Circle of Burgundy remained a part of the Holy Roman Empire, calls for assistance by Spanish representatives at French invasions under Louis XIV remained unanswered as well. Neither side executed the obligations contained in the Transaction of Augsburg ! Leopold I (1640-1705) called for assistance of the Circle of Burgundy at Louis XIV's aggression in 1683, but most of these troops were stuck in the parallel siege of Vienna. During the Nine Years' War (1688-1697), requests from the Spanish Netherlands were subject to a discussion on the nature of their specific status as a Circle of the Empire. Was a financial contribution to the military forces of the Empire sufficient to be counted as a full member, or had the Spanish Netherlands been merely associated to the Empire in case of military peril ?

In the preamble to the Treaty of the Grand Alliance (7 September 1701), Britain and the Dutch Republic had invoked the rights of the Holy Roman Empire to the Southern Netherlands, qualifying them as fiefs of the Empire, just as the Spanish domains in Italy (DU MonT, La Vérité du fait, p. 48). During the War of the Spanish Succession, the Empire counted the Southern Netherlands as contributors to the common military effort, but without any countervailing advantage. Joseph Clement of Bavaria, Bishop of Liège and Elector-Archbishop of Cologne, allowed French troops from the Southern Netherlands in his own fortresses, pretending they ought to be considered as troops of an Imperial circle. The Imperial court of Joseph I, however, preferred contingents from the Westphalian Circle and considered the Circle of Burgundy as not an integral part of the Holy Roman Empire. Max Emanuel of Bavaria did saw them as part of the Empire, but only in case he would rule over them as a sovereign as a compensation for the loss of Bavaria after the battle of Blenheim (1704), in order to keep his influence in Imperial politics. In the Wittelsbach's view, Philip V's accession to the Spanish throne was linked to the quality of ruler of the Southern Netherlands, automatically classifying his troops as Imperial ones, sent out by an Imperial Circle. Joseph I and Leopold I, however, firmly denied that Lorraine and the Southern Netherlands were ordinary members of the Holy Roman Empire. They served as mere keys and borders to the Empire, and could only count on the Emperor's personal Rath und That (verbal and physical support). See Émile DE BORCHGRAVE, Histoire des rapports de droit public qui existèrent entre les provinces belges et l'Empire d'Allemagne depuis le démembrement de la monarchie carolingienne jusqu'à l'incorporation de la Belgique à la République Française Bruxelles, Palais des Académies, 1871 (Mémoires de l'Académie Royale de Belgique; XXXVI), p. 292, 304, 313-314, 327-329 and 331. De Borchgrave finds support in Johann Jakob MOSER's Teutsches Staatsrecht, Frankfurt/Leipzig, s.n., 1774, I, p. 317-319. The situation was not without relevance the British diplomacy in the multilateral game around the Company, since George I, as Elector of Hanover, could not be seen to commit aggression on a member of the Empire (Brendan SIMMS, Three Victories and a Defeat: The Rise and Fall of the First British Empire, London, Penguin, 2008, p. 193-194). 
possessions on the one hand, and his dominions in the Southern Netherlands, as heir to the Dukes of Burgundy, on the other, was contrary to common sense. Charles VI received the Southern Netherlands as heir of part of Charles II's composite monarchy, and not separately as the successor of the House of Burgundy, as Neny alleged on the basis of the Rastatt and Barrier Treaties ${ }^{136}$. For Neny, the mention of the union between the Austrian Netherlands and the hereditary dominions of the House of Austria within the Empire equalled the construction of the dominions of Maximilian I of Habsburg. Charles VI was nothing but a specific legatee in Charles II of Spain's will. He could only have succeeded as a universal heir to the Spanish throne, if the latter document would have appointed him so. Instead, Charles II's will, which designated Philip of Anjou as his successor, ruled out the possibility to appoint Charles of Habsburg as King of Spain. Neny further supported his claim by pointing to the distinction made in article II of the Barrier Treaty, which stipulated a link between sovereignty over any part of the Southern Netherlands, on the one hand, and the sovereignty over the Habsburg hereditary dominions in the Holy Roman Empire, on the other. The Barrier Treaty thus excluded a transfer of sovereignty to a French (or Wittelsbach, Farnese...) prince, linking the Southern Netherlands to the traditional Habsburg family ${ }^{137}$. Moreover, Neny contested that the conditions under which Charles VI obtained the Southern Netherlands, were of the same nature as those they were under during Charles II's reign. In reality, the Barrier Treaty established an entirely new legal regime for the Southern Netherlands. Consequently, Charles ought to be seen as a specific legatee, and not as a universal heir. Thus, obligations and limitations of all kinds pending on the Spanish Netherlands before 1715 could not be applicable any more without explicit confirmation... and Charles VI's royal consent ${ }^{138}$.

Neny's third argument was based on an alleged right of conquest on the basis of which Charles VI would have obtained the Southern Netherlands, allowing the Emperor to start with a clean sheet ${ }^{139}$. As far as the military events of the War of the Spanish Succession were concerned, Neny allowed himself a great deal of liberty. He had to reconcile two opposites: one the one hand, Charles VI needed the right of conquest in order to undo the existing limitations on his sovereignty in the Southern Netherlands. On the other hand, mainly British and Dutch-financed German troops had effectively conquered his new territories ${ }^{140}$. In his zeal to serve Charles VI's cause, Neny obscured the substance of the Dutch assistance in beating the French in Flanders, and even accused them of lack of sincerity in their commitment to the general obligations foreseen by the Treaty of the Grand Alliance ${ }^{141}$. As a proof of this, the States-General allegedly refused to cede the Spanish residence in The Hague to Charles VI, despite strong instances by Sinzendorf ${ }^{142}$. This is without doubt the weakest part of Neny's argumentation: Archduke Charles' accession to the Imperial throne had been uneforeseen, after his brother Joseph I's sudden decease. This course of events pushed Britain, not the Dutch Republic, to desert the Grand Alliance and agree to French proposals of peace, which had previously been refused by Imperial general Eugene of Savoy (1663-1736), the British commander Marlborough (1650-1722) and Heinsius, pensionary of Holland (1641-1722) ${ }^{143}$. As far as the war was concerned, the Dutch did fight by the Emperor's side until the Battle of Denain (24 July 1712), whereas the Duke of Ormonde, commander of the British forces, had received his famous "restraining orders" from Whitehall (31 May 1712), where a peace-inclined Tory government

${ }^{136}$ NENY, Démonstration de l'injuste et chimerique pretention, op. cit., p. 5.

${ }^{137}$ Ibid., p. 7.

138 Ibid.

139 Ibid.: le droit de Conquête, qui l'exempte de toutes les obligations, conventions \& contracts de quelque nature qu'ils soient, que les autres Possesseurs pourroient avoir fait, \& par consequent les Sujets en demeurent aussi libres, \& independants sous la Domination du nouveau Souverain Conquerant.

140 Neny did not deny this, but found it nothing both a natural consequence of the Grand Alliance, for which no reward was due to them (NENY, Démonstration de l'injuste et chimerique pretention, op. cit., p. 26).

${ }^{141}$ E.g. concerning the conquest of Italy, which was left to the Austrians.

142 NENY, Démonstration de l'injuste et chimerique pretention, op. cit., p. 32.

143 BÉLY, "Les larmes de M. de Torcy: la leçon diplomatique de l'échec, à propos des conférences de Gertruydenberg (mars-juillet 1710)”, Histoire, Économie \& Société 1983, No. 3, p. 429-456. 
was negotiating with Louis XIV. Neny further accused the Dutch of passive bribery. The city and citadel of Lille, the most formidable conquest of Louis XIV (1667), which had fallen in 1708, was returned to France at the Treaty of Utrecht. According to Neny, France and the Princess of Épinoy had paid the Dutch plenipotentiaries at Utrecht to return this important place in the Southern Netherlands to France, and thus take it from Charles VI, in whose name the town had been conquered ${ }^{144}$. The conclusion of the Peace at Utrecht without Imperial consent, finally, constituted a betrayal and a violation of article VIII of the Treaty of the Grand Alliance ${ }^{145}$.

Barbeyrac, on the other hand, clung on to the possession of the Southern Netherlands in the same state Charles II had enjoyed it ${ }^{146}$. Accessorium sequitur principale: limitations contracted by Philip IV for the whole of his territories and still intact at the time of Charles II's decease, did not disappear at Charles VI's accession. Cela est fondé sur une règle incontestable du Droit des Gens, aussi bien que du Droit Civil147. Secondly, if Neny considered the Burgundian Netherlands as a separate entity, from Maximilian I to Charles VI, would this imply that all intervening acts of public law, such as the Augsburg Transaction or the Treaty of Munster, would not apply ? On ne sauroit se persuader, que Sa Majesté Impériale approuve cette maniére de plaider devant le Tribunal de toute l'Europe, \& les contradictions où nos deux Avocats de la Compagnie d'Ostende font tomber leur Auguste Souverain ${ }^{148}$.

In spite of his strong arguments on the general nature of Charles of Habsburg's accession to the Southern Netherlands, Barbeyrac did in part misread Neny's argument. The latter did not contend that the inhabitants of the Southern Netherlands were excluded from overseas trade at the time of the conclusion of the Treaty of Munster. Articles V and VI only concerned les Espagnols Castillans qui negocioient seuls aux Indes \& y possedoient des Seigneuries, Villes, Forteresses, \&c. In other words, there was no reason for Philip IV to present an extensive interpretation of the word "Castillans", since his Spanish subjects were the only ones actually allowed to sail to the Indies ${ }^{149}$. Consequently, any bans on the liberty of his subjects in the Southern Netherlands were a purely domestic affair, and not guaranteed to the Dutch Republic as a treaty partner on the inter-sovereign level. Irrespective of the above-mentioned discussion on the nature of Charles VI's succession (specific or universal legatee, answerable or not for debts and limitations imposed by the deceased), the international nature of the impediments imposed on the inhabitants of the Southern Netherlands can be seen as doubtful. Prohibitions such as that of 1598 decreed by Philip II or by Philip III in $1604{ }^{150}$ were a domestic affair ${ }^{151}$, concerning the organisation of the composite Spanish monarchy, and thus not pertinent to the international and bilateral question between the Dutch Republic and the sovereign in the Southern Netherlands ${ }^{152}$. The latter had the competence to forbid, as well as to give his

144 NENY, Démonstration de l'injuste et chimerique pretention, op. cit., p. 31.

$145 \mathrm{Ibid}$. On this question, see Réal de Curban, Science du Gouvernement, V, p. 637 : alliance partners cannot -in this French author's view- be unreasonably compelled to stick to their initial alliance, if the initial objective has been reached. Charles VI's insistence on continuing the war with France could thus be seen as unreasonable, since he already had obtained the Spanish Netherlands, Milan, Sardinia and Naples.

146 Art. I, Barrier Treaty.

147 BARBEYRAC, Défense du droit, op. cit., p. 105.

148 Ibid., p. 112.

${ }^{149}$ NENY, Démonstration de l'injuste et chimerique pretention, op. cit., p. 20.

150 Restricting all trade with the Spanish Indies to Spaniards or Portuguese, excluding all foreigners, including his own non-Castillian subjects, such as Neapolitans, Aragonese or Sicilians (Historie of Tegenwoordige Staat van Alle Volkeren, Amsterdam, Isaak Tirion, 1738, X, p. 449; Memorandum VOC, DU MONT, La Vérité du fait, p. 88).

${ }^{151}$ HUISMAN (La Belgique commerciale, op. cit., 11) accessorily pointed to the granting of a general commercial concession in the East Indies to his subjects in the Spanish Netherlands by Philip IV in 1640, cancelling out the Transport's eighth article (see as well letter from the Cardinal-Infant, Governor-General of the Spanish Netherlands, to the Antwerp Magistrate, Brussels, 25 October 1640, Du MonT, La Vérité du fait, op. cit., p. 84: Sa Majesté [...] pour beneficier les bons Fideles Sujets de par deça, Elle leur à fait ouverture du Commerce des Indes Orientales avec faculté d'y pouvoir entrer, ensemble à tous les Inhabitans du Septentrion, non obstant que cela n'ait été permis jusques aujourd'bui.

152 Neny, Demonstration, p. 17. 
subjects permission ("to bind as well as to unbind": Ejus est solvere, cujus est ligare, cf. infra). Consequently, on instigation of the Count of Bergeyck (1644-1725) ${ }^{153}$, Charles II allowed the creation of a Compagnie Roiale des Pais-bas (7 June 1698) with the explicit competence to trade Aux Indes Orientales, \& en la Guinée [...] Sans contrevenir aux Traitez, de Paix que nous avons avec la France, l'Angleterre, les Provinces-Unies, \& autres Princes, \& Estats de l'Europe ${ }^{154}$.

Du Mont, finally, reformulated the application ratione personae of article $\mathrm{V}$ in rhetorically appealing terms. First, the Spaniards or Castillians mentioned in article V of the Treaty of Munster, were the inhabitants of the Iberian peninsula who could trade with the Indies, not the inhabitants of the Southern Netherlands, excluded in 1598 by Philip II and afterwards by Philip III ${ }^{155}$. Thus, how could Philip IV have excluded them from a trade they were not involved in ${ }^{156}$ ? Secondly, the Treaty of Munster could not treat them as Spaniards, since they were only part of a composite monarchy: Les Peuples du Païs Bas Autrichien ne sont Espagnols ni par Nature, ni par Conquête, ni par Subjection, ni par Dependance, ni par Incorporation, ni par aucune sort d'Union politique157. Finally, if "Spaniards" in article V had to be read as "subjects and inhabitants of the Southern Netherlands", how could Barbeyrac or Westerveen explain the sentence stipulating that he inhabitants and subjects [...] would keep their Navigation as they have it at present in the East Indies, without any further extension of it ?158 If only the Castillian subjects of Philip IV were allowed to sail to the East Indies, the interdiction of article V could not have been applicable to Aragonese, Neapolitans, Valencians, Catalans or any other people of the Spanish Monarchy. Consequently, Du Mont could present his European readers with a simple syllogism. The Spaniards in article V were those who had the right to sail to the East Indies, in 1648 (Maior). The inhabitants of the Southern Netherlands, even if we assume they were Spaniards, did not have the right to sail and trade there (Minor). Thus, the inhabitants of the Southern Netherlands were not included in the reservation Philip IV made towards the United Provinces (Conclusion) ${ }^{159}$.

\section{Cause theory}

Neny further argued that, even if the Treaty of Munster had been applicable to the Southern Netherlands, the main motive for Philip IV to introduce a limitation on trade with the Indies, was that he could set one category of his subject apart, and favour another, i.e. the inhabitants of Spain itself. Charles VI, however, did not have this faculty, and was confronted with a purely comminatory clause, that was not any more counterbalanced by an advantage. Neny applied the causation theory from general contract law to the agreement between Philip IV and the Dutch Republic and concluded that the limitations imposed on Philip IV's Belgian subjects were not any longer justified ${ }^{160}$.

153 DE SCHRYVER, Jan van Brouchoven graaf van Bergeyck 1644-1725 : een halve eeun staatkunde in de Spaanse Nederlanden en in Europa, Brussel: Paleis der Academiën, 1965.

154 NenY, Démonstration de l'injuste et chimerique pretention, op. cit., p. 18 ; DU MONT, La Vérité du fait, op. cit., p. 85.

155 Leaning on the conditionality of the donation of the Southern Netherlands by Philip II to Albert and Isabella, Du MONT (La Vérité du fait, op. cit., p. 30) argued that the archdukes' childless existence had revoked the entire act, including the trade restrictions. Consequently, the only interdiction the Spanish Netherlands were under, in his view, was the internal one, imposed by Philip III, becoming applicable at the extinction of Philip II's act. Qui ne sçait, que cette Donation ne subsiste plus? Et quel Droit peut on tirer d'un Contract éteint, \& fini, en vertu de ses propres Stipulations, il y a plus de cent ans?

156 Du MONT, La Vérité du fait, op. cit., p. 29.

157 Ibid., p. 28.

158 Ibid.

159 Ibid., p. 29

160 Du Mont, La Vérité du fait, op. cit., p. 15 argued that Charles II of Spain had obtained trading privileges for the Southern Netherlanders on an indirect basis. Negotiating trade argreements with Britain (23 May 1667 and in July 1670), Spanish diplomats had asked for the same trading advantages in the Indies as the Dutch had obtained. 
Barbeyrac, again, saw this as an ungrateful attitude by Charles VI as an heir to part of the Spanish monarchy. Accepting the gains from an inheritance implied paying for the annexed debts as well ${ }^{161}$. Moreover, in the VOC's argumentation, the Dutch Republic would never have consented in the Treaty of Munster without the exclusion of the Spanish Netherlands from the East India trade. In other words, the cause theory was used on the Dutch side as well. If Charles VI unilaterally removed the essential motive for the 1648 peace treaty, it would become void as a whole ${ }^{162}$. This had consequences for Munster's confirmation in the Barrier Treaty as well: if the exclusion had been the core of the peace treaty, this could not have been ignored at the time of the 1714-1715 Antwerp conferences.

However, the imbalance between gain and cost for Charles VI was striking. The Emperor started as sovereign with a clean sheet and new burdens incomparable to those put upon the Southern Netherlands under Charles II's sovereignty. The Emperor acquired Tournay, but had to agree to the cession of several smaller entities in Flanders and Guelders to the States-General ${ }^{163}$. Not only the debts contracted before and during the War of the Spanish Succession, the closure of the Scheldt or the alleged limitations in trade with the Indies, but foremost the stationing of Barrier garrisons and the upkeep of considerable armed forces at his own expense ${ }^{164}$, had been alien to the previous regimes in the Southern Netherlands. The customs regime was tailor-made for the Dutch, who abused of the simultaneous Austro-Turkish war (1716-1718) in the Balkans to impose their tyrannique Domination in import and export duties ${ }^{165}$. Article XXVI of the Barrier Treaty, relative to trade, was strictly limited to the latter aspects and could not be extended to the Indies ${ }^{166}$. Moreover, the Dutch soldiers at Namur, Ypres, Menin, Tournay, Furnes or Termonde were exempt of import duties, which they abused to sell Dutch cheese, fish and butter to the local population, to the detriment of Belgian merchants ${ }^{167}$. During their administration of the greater part of the Southern-Netherlands (the so-called "Anglo-Dutch Condominium in Flanders and Brabant ${ }^{168}$ ), Neny judged the Dutch had extorted the population and corrupted public institutions ${ }^{169}$.

Finally, Neny remarked with irony that the Dutch invocation of Alexander VI's partition of the Indies in 1494 between Spain and Portugal equalled recognising a state of affairs which all powers in Europe ${ }^{170}$, including the Dutch themselves, strongly challenged in the seventeenth century ${ }^{171}$. What else did the Republic try to impose in articles V and VI of the Treaty of Munster, than a partition of the world between two sovereigns?

The sovereignty of the Dutch Republic and the VOC, an usurpation?

161 Barbeyrac, Défense du droit, op. cit., p. 107 : qui refusoit de payer ses Dettes; ou de se soûmettre à la Condition imposée; sous prétexte que par là il ne retire pas de la Succession tout le profit qu'il en auroit autrement.

162 VOC memorandum, DU MONT, La Vérité du fait, op. cit., p. 90. Supplementary, the violation of articles V and VI could be seen as rendering the whole treaty void, following Grotius, who prescribed the explicit mention of any incidental nullities (VATTEL, Le Droit des Gens, op. cit., Book II, \$202).

163 NENY, Démonstration de l'injuste et chimerique pretention, op. cit., p. 27-28.

164 Art. XX, Barrier Treaty; Neny, Demonstration, p. 27.

165 NENY, Démonstration de l'injuste et chimerique pretention, op. cit., p. 28.

${ }^{166}$ Du MONT, La Vérité du fait, op. cit., p. 30, not applicable to trade between Charles VI's subjects and other nations.

${ }_{167}$ NENY, Démonstration de l'injuste et chimerique pretention, op. cit., p. 30.

168 Augustus Johannes VeEnendAAL sr., Het Engels-Nederlands condominium in de Zuidelijke Nederlanden tijdens de Spaanse successieoorlog 1706-1716, Utrecht, Kemink, 1945.

${ }^{169}$ NENY, Démonstration de l'injuste et chimerique pretention, op. cit., p. 26 : tant par les exactions rapineuses qu'Ils y ont pratiquées de toute maniere, que par la vente de plusieurs Emplois qui étoient vacants.

170 Du MONT, La Vérité du fait, op. cit., p. 13-15, pointing to Louis XIII's defence against Spanish maritime hegemony, La Cour de France ayant jugé [...] que son Droit de Navigation, de Commerce, d'Habitation, de Colonie, \& de Conquêtes, par toute Mer, \& par toute Terre; decouverte, \& à découvrir, n'avoit pas besoin du consentement de l'Espagne.

171 NENY, Démonstration de l'injuste et chimerique pretention, op. cit., p. 33. DU MONT, La Vérité du fait, op. cit., p. 32: Le Roy de France est bon Catholique, \& il ne laisse pas de posseder de grandes \& vastes Regions aux indes Occidentales, contre les Dispositions formelles de la Bulle. 
In his closing remarks, Neny challenged the opponent's very existence in public international law. Basing his reasoning on the mention of Emperor Rudolph II (1552-1612) on the donation by Philip II of the Southern Netherlands to Albert and Isabella, Neny equalled the omission of Emperor Ferdinand (16081657) in the Treaty of Munster to a breach of Imperial law, leading to nullity. The States-General of the Dutch Republic lacked any Titre competent \& legitime to count as sovereigns, but were in reality mere Sujets \& Vassaux de Sa Majesté Imperiale et Catholique, à qui Ils doivent obéir comme à Leur Souverain legitime172. Recognition by the elder branch of the House of Habsburg (that of Philip IV) was independent from that of the younger (Austrian), the Treaty of Munster between Spain and the Republic lacking the Emperor's ratification concerning the Southern Netherlands, territories of the Empire ${ }^{173}$. The restitution of Maastricht and the illegal retention of ecclesiastical goods (art. XLIII, Treaty of Munster) were further signs of the implacable hatred of the Dutch Regents against their Southern neighbours ${ }^{174}$. If healthy competition from the Ostend Company drove prices down to more reasonable levels, to the common benefit of the Republic's population, the Dutch trading companies were solely concerned with their shareholders' interest, most of them not even residing in the Seven Provinces ${ }^{175}$.

Du Mont respected the Treaty of Munster regarding the Republic's recognition by Philip IV. However, he had trouble in conceiving the Heren XVII, or the VOC's principal administrative organ, as exercising the organisation's sovereign powers in Asia. How could these men be subjects of the Dutch Republic's provinces, and, at the same time, wield sovereign power thousands of kilometres away ? The seizure of Ostend ships was mainly the work of the VOC, who represented in their own right to the States-General, and against whom Neny and du Mont had to argue ${ }^{176}$.

\section{Ejus est solvere, cujus est ligare: Charles VI could undo what Philip III had imposed}

In his 1726 memorandum, Du Mont de Carelskroon referred to the adagium ejus est solvere, cujus est ligare, \& cui unum competit, eidem utique \& alterum. This religious phrase was frequently used in canon law, and signifies that the authority conferred upon a person or institution to dissolve, or to pronounce sanctions, is indispensably linked to the capacity to found or to bring together ${ }^{177}$, since both are two sides of the same (contractual) medal ${ }^{178}$. E.g. a bishop cannot forgive an excommunicated individual without papal instruction, since only the pope has the competence to admit and exclude from the Church ${ }^{179}$. It is impossible to unilaterally quit a contractual relationship, if its existence was dependent on the other party's

172 Ibid, p. 41.

173 Ibid, p. 39.

174 Ibid, p. 25.

175 Ibid, p. 25.

176 Il est inconcevable, qu'une Société de mille personnes au plus, qui sont Presque tous Bourgeois de quelque Ville de Holande, responsibles en leurs biens, \& en leurs vies à sa Jurisdiction civile \& criminelle du Magistrat, \& qui ont pour Chefs, ou plutôt pour premiers Administrateurs, dix sept Hommes, soumis comme eux à la Puissance Souveraine, \& Municipale de la Province, \& de la Ville, où ils habitent [...] que ces mille Particuliers forment en Asie une Republique, formidable à tous les Princes de ces Regions là, à l'exception peut-être du Sophy, du Mogol, \&o des Rois de la Chine, \& du Japon (DU MonT, La Vérité du fait, op. cit., p. 36). On the VOC and its incipient stages in East Asia, see J. A. SOMERS, De VOC als volkenrechtelijke actor [SI-EUR], Gouda, Sanders, 2001.

177 E.g. Pierre Toussaint Durand De Maillane, Dictionnaire de droit canonique et de pratique bénéficiale, conféré avec les maximes et la jurisprudence de France, Lyon, Benoît Duplain, 1770, p. 175 ; J. Pontas, Dictionnaire de cas de conscience ou decisions des plus considerables difficultez touchant la Morale \& la Discipline Ecclésiastique, Paris , Le Mercier, 1726, p. 975 (a priest suspended by a sentence pronounced by an ecclesiastical court of law can only be absolved of it by the bishop or Metropolitan who is his hierarchical superior).

${ }^{178}$ François BABIN, Conférences ecclésiastiques du diocèse d'Angers, sur les censures, Anger/Paris, Dubé, Guerin, 1767, p. 608 : l'ordination \& le bénéfice qui y étoit toujours joint, formoient une espèce de contrat sinallagmatique, dont une des obligations de la part du clerc ordonné, étoit de demeurer fixe dans le poste qui lui étoit assigné. CE contrat passé avec l'église ne pouvoit se dissoudre que par l'évêque qui étoit son représentant; c'est ce qui a donné lieu d'appliquer aux démissions des bénéfices, les maximes, ejus est solvere cujus est ligare; illius est destituere cujus est instituere.

179 Michel ANDRÉ, Cours alphabétique et méthodique de droit canon dans ses rapports avec le droit civil ecclésiastique, Paris, Boullotte, 1859, p. 286. 
consent ${ }^{180}$. If the Treaty of Munster did not apply to the Southern Netherlands and Philip III did install an internal prohibition on his "Belgian" subjects, Charles VI, as his successor, could lift it again, just as Charles II had done when allowing for the creation of a Company in 1698. William III and the StatesGeneral had not uttered a single reproach at that time. Consequently, the Dutch Republic had to abstain from intervention in these internal matters. Si cette Regle est bonne entre les particuliers, elle vaut à plus forte raison entre le Souverain, \& son Peuple, \& quand ces deux sont d'accord, les Etrangers n'ont rien ày revoir ${ }^{181}$.

\section{Multilateral diplomacy}

Il me paroit que c'est une affaire désespérée; ils [the plenipotentiaries at the Soisson Conference] avouent que le droit de Sa Majesté [Charles VI] est clair, mais un droit de convenance qu'ils appellent, est entièrement en faveur de Leurs Hautes Puissances [States-General], et n'est d'aucune considération pour les sujets des Pays-Bas autrichiens.

Karel Filips Pattijn to Visconti, Austrian representative in London, $1728^{182}$

Rhetoric on the Ostend Company should not be framed as a mere bilateral dispute around the freedom of navigation on the high seas. Bilateral aspects of the Ostend Company-quarrel, as examined until now in this contribution, belong to a classical scheme of diplomatic and legal history ${ }^{183}$. Yet, our analysis could not be complete without the implication of Europe's multilateral diplomatic system, as the words of Karel Filips Pattijn quoted above indicate ${ }^{184}$. The working of international relations is not a product of crude power configurations and political compromise. Implicit norms or habits shape the expression of the latter, and constitute the essential nexus between diplomatic history and academic attempts at systematisation through legal concepts ${ }^{185}$. Classical international law in scholarly treatises ${ }^{186}$ and political practice consolidated in preceding treaties ${ }^{187}$ were elements of a diplomatic culture, serving as building blocks for reasoning.

Manuals such as those of Wicquefort ${ }^{188}$, Caillières ${ }^{189}$ or la Sarraz ${ }^{190}$ emphasized the intricate links between legal theory and diplomatic practice. Although the latter was considered as the sole and privileged way to

${ }^{180}$ Encyclopédie méthodique, Paris/Liège, Panckoucke/Plomteux, 1783, III, “démission”, p. 609: l'ordination et le bénéfice qui y étoit toujours joint, formoient une espèce de contrat sinallagmatique, dont une des obligations de la part du clerc ordonné, étoit de demeurer fixe dans le poste qui lui étoit assigné. Ce contrat passé avec l'église ne pouvoit se dissoudre que par l'évêque qui étoit son représentant; c'est ce qui a donné lieu d'appliquer aux démissions des bénéfices, les maximes ejus est solvere cujus est ligare : illius est destituere cujus est instituere.

181 Du MONT, La Vérité du fait, op. cit., p. 33.

182 Quoted in HuISMAN, La Belgique commerciale, op. cit., p. 438.

183 DE PAUW, Mare Liberum, op. cit..

184 DHONDT, "Lodewijk XIV als spelverdeler in de Spaanse Successie", in De Achttiende Eeuw: Tijdschrift van de Belgisch-Nederlandse Werkgroep de $18^{\text {de }}$ eeun, XLII (2010), No. 2, p. 283-319.

185 DHONDT, "Looking Beyond the Tip of the Iceberg: Diplomatic Praxis and Legal Culture in the History of Public International Law", in Rechtskultur - Zeitschrift für Europäische Rechtsgeschichte/European Journal of Legal History/Journal européen d'histoire du droit 2 (2013) [Methode der Rechtsgeschichte und ihrer Nachbarwissenschaften beim Umgang mit rechtshistorischen Quellen], p. 31-42.

186 LESAFFER, "The Classical Law of Nations (1500-1800)", in Alexander OrAKHELASHVILI (ed.), Research Handbook on the Theory and History of International Law, Chelentham, Edward Elgar, 2011, p. 408-440, Jean-Mathieu MATTÉI, Histoire du droit de la guerre 1700-1819, Aix-en-Provence, PUAM, 2006 (Collection d'histoire du droit. Thèses et travaux).

${ }^{187}$ LESAFFER (ed.), Peace treaties and international law in European history: from the Late Middle Ages to World War One, New York, Cambridge UP, 2004.

188 BÉLY, "L’ambassadeur et ses fonctions de Wicquefort", in Alain Pekar LEMPEREUR \& Aurélien COLSON (dir.), Négociations européennes d'Henri IV à l'Europe des 27, Paris, AC2Médias, 2008, p. 53-63; Heidrun Kugeler, "'Le parfait Ambassadeur". Zur Theorie der Diplomatie im Jahrhundert nach dem Westfälischen Frieden”, in KugELER, Christian SEPP \& Georg WOLF (Hg.), Internationale Beziehungen in der Frühen Neuzeit. Ansätz̨e und Perspektiven, Hamburg, LIT, 2006 (Wirklichkeit und Wahrnehmung in der Frühen Neuzeit ; Hrsg. von Winfried SCHulzE), p. 180-211; Jean RoussET DE MISSY, Mémoires sur le rang et la préséance entre les souverains de l'Europe 
access the inner workings of the international system, its conceptual language was asserted to be drenched in legal terms and the broader intellectual tradition of Roman and natural law. Primary legal documents, such as treaties, conventions, declarations or manifesto's, were eagerly published in collections such as Abraham Friedrich Glafey's update of the Theatrum Europaeum ${ }^{191}$ and the widespread Les Interêts présens des puissances de l'Europe, a French adapted version by Jean Rousset de Missy ${ }^{192}$. Combined with memoranda and day-to-day correspondence in the vast French ${ }^{193}$ and British ${ }^{194}$ diplomatic archives, historians and jurists alike can unearth the practical legal culture of the "Trente Heureuses" following the Treaty of Utrecht, which have until now mostly been explained as a transitory parenthesis, the product of coincidental cordial relations between the main protagonists (Dubois, James Stanope, Fleury, Horatio Walpole195).

\section{The construction of the Anglo-French alliance}

Most of European diplomacy between 1717 and 1731 turned around the apportioning of the duchies of Parma, Piacenza and the Grand-Duchy of Tuscany ${ }^{196}$. The Emperor had obtained a dominating position on the Italian peninsula after the Utrecht treaties, following the confiscation of the Duchy of Milan in 1700 and the conquest of Naples in 1707197. Previously, Spain did hold the upper hand in the Italian balance, as a result of Charles V's military campaigns in the $16^{\text {th }}$ century and the inheritance of his grandfather, Ferdinand of Aragon. As the cards were redistributed during the War of the Spanish Succession, Britain had foreseen to install the Duke of Savoy as King of Sicily, as a counterweight ${ }^{198}$.

The remaining Italian princes, however, feared Imperial pressure would lead to German domination. Duke Francesco Farnese of Parma-Piacenza (1678-1727), whose agent Alberoni had risen to Philip V of Spain's royal favourite ${ }^{199}$, hoped for a return of the traditional Bourbon-Habsburg antagonism. If Spain's new monarch reclaimed the position once held by the Spanish Habsburgs, Charles VI would have a fully-fledged opponent. A "Spanish Risorgimento" in the Mediterranean after Utrecht did not only

et entre leurs ministres représentans suivant leurs différens Caractères. Pour servir de supplement à l'ambassadeur et ses fonctions de Mr. de Wicquefort, Amsterdam, François l'honoré, 1746.

189 François DE CAILLIERES, De la manière de négocier avec les souverains, Amsterdam: au dépens de la Compagnie, 1716 ; LEMPEREuR, "Les manières de l'orateur-négociateur chez François de Caillières (1716)" in LEMPEREUR \& COLSON, Négociations européennes, op. cit., p. 65-77.

${ }^{190}$ Jean DE LA SARRAZ DU FrANQUESNAY, Le ministre public dans les Cours étrangères, ses fonctions, et ses péerogatives, Amsterdam, Au dépens de la compagnie, 1731.

191 Frank-Steffen SCHMIDT, Praktisches Naturrecht zwischen Thomasius und Wolf: Der Völkerrechtler Adam Friedrich Glafey (1692-1753), Baden-Baden, Nomos Verlag, 2007 (Studien zur Geschichte des Völkerrechts; 12); Christoph Herrmann SCHWEDER, Theatrum Historicum praetensium et controversiarum illustrium, oder bistorischer Schauplatz der Ansprüche und Streitigkeiten hoher Potentaten und anderer regierender Herrschafften in Europa, s.l., s.p., 2.v.

192 Rousset DE MISSY, Les intérêts présens des puissances de l'Europe, Fondez sur les Traitez conclus depuis la Paix d'Utrecht inclusivement, \& sur les Preuves de leurs Prétentions particulieres, La Haye: Adrien Moetjens, 1733, 2 v.; ID., Recueil bistorique d'actes, négotiations, mémoires et traitez, depuis la Paix d'Utrecht, La Haye: Scheurleer, 1728, 23 v.

193 Archives du Ministère des Affaires Étrangères et Européennes (La Courneuve) [further : AMAE], series Correspondance Politique [further : CP] and Mémoires et Documents [further : M\&D].

${ }^{194}$ National Archives [further : NA], series State Papers [further: SP], France (78).

${ }^{195}$ Le Roy Ladurie, L'Ancien Régime, T. 2: l'absolutisme bien tempéré, Paris, Hachette, 1991, p. 93.

196 GEHLING, Saint-Saphorin, op. cit.

${ }^{197}$ José Ignacio RUIz Rodriguez \& Pier Luigi Nocella, “Cambio dinástico en los dominios de la Italia del sur y la Guerra de Sucesión”, in Friedrich EDELMAYER LEON SANZ \& RUIZ Rodriguez (eds.), Hispania Austria III: der Spanische Erbfolgekrieg - La guerra de Sucesión española, Wien: Verlag für Geschichte und Politik, 2008 [Studien zur Geschichte und Kultur der Iberischen und Iberoamerikanischen Länder/Estudios sobre historia y cultura de los países ibéricos e iberoamericanos ; 13], p. 295-317.

198 Derek MCKAY, "Bolingbroke, Oxford and the defence of the Utrecht Settlement in Southern Europe”, in EHR LXXXVI (1971), nr. 339 (Apr), p. 264-284.

199 BourgeOIS, La diplomatie secrète au XVIIIe siècle, Paris, Arman Collin, 1910, II. 
benefit Spain itself, but was welcomed by Italian rulers ${ }^{200}$. The children born from Philip V's marriage with Elisabeth Farnese ${ }^{201}$ could thus be seen as Parmesan, as well as Bourbon princes. Their succession in the duchies of Parma and Piacenza, as well as in the Grand-Duchy of Tuscany, where the Medici-family faced extinction in the male line, would prevent an Imperial take-over of these fiefs of the Empire.

France and Britain did intervene when Spain invaded first Sardinia and then Sicily, but were not averse to a more balanced distribution of power on the peninsula. When Philip V was forced to adhere to the clauses of the Treaty of the Quadruple Alliance in February 1720202, the solution imposed on him was not punitive. France and Britain imposed themselves as mediators, guaranteeing a strict observance of the partition of the Spanish composite monarchy agreed at the end of the War of the Spanish Succession. In an ongoing permanent process of negotiation, the diplomatic efforts deployed by the mediators continued the coercive work of their armies ${ }^{203}$. The States-General did pass a resolution in favour of accession to the Quadruple Alliance ${ }^{204}$. Yet, Amsterdam, worried about the fall in Dutch commerce with Spain since the death of Charles II, preferred to stay aloof from the alliance. Consequently, the Republic acted as medius in bello, able to trade with all contending partners alike 205.

\section{Cambrai}

Amsterdam-induced abstention in the War of the Quadruple Alliance switched to active engagement once the Ostend Company was on the table. As the general picture of Dutch commercial activity turned grim, with diminishing returns from the Spanish dominions or the Levant, the East India markets were the prime asset of the Republic's trade ${ }^{206}$. The Dutch, party to, invoked this treaty to bring both Britain and France to military action. Charles VI's decision to grant permission for the Ostend Company, published on 28 July $1723^{207}$, constituted a casus foederi ${ }^{208}$. After his unsuccessful remonstrances, Pesters, usually based in Brussels, was sent to Hanover, George I's Summer residence, to convince George I's ministers that the Ostend affair fell within the perimeter of the bilateral Anglo-Dutch Treaty of Guarantee of $1716^{209}$ and, thus, required action. On 2 October 1723, a new anti-Ostend bill completed earlier decisions of 26 April,

${ }^{200}$ Christopher STORRS, "The Spanish Risorgimento in the Western Mediterranean and Italy 1707-1748”, in European History Quarterly LXII (2012), No. 4, p. 555-577.

201 DHONDT, "Bring this mad woman to reason! Elisabeth Farnese as a female ruler in 18th Century Europe", in Bruno DEBAENST et al. (eds.), (Wo)men and the Law: Acta of the XIXth European Forum of Young Legal Historians, Brussels, Royal Academy of Sciences, 2014 (Iuris Scripta Historica) (forthcoming).

202 Philippi V. Regis Hispaniarum Accessio iterata, \& per Plenipotentiarium suum, ad Tractatum sive Concordatum Londini 2. Augusti ejusdem anni initum, extenso, The Hague, 17 February 1720, CUD, VIII/2, nr. XI, p. 26-27.

203 DHONDT, "La représentation du droit dans la communauté des diplomates européens des « Trente Heureuses (1713-1740)", in Tijdschrift voor Rechtsgeschiedenis - Revne d'Histoire du Droit - The Legal History Review LXXXI (2013), No. 3-4 (forthcoming).

204 ISRAEL, The Dutch Republic, op. cit., p. 988.

205 Johann Ludwig KLÜBER, Droit des gens moderne de l'Europe, Paris, Guillaumin, 1874, \ 279, p. 353. Commercial competition constituted a valid motive for the union of the Maritime Powers. In situations where one of them kept out of an armed conflict, it could reap profits from trade diverted from its competitor. During Louis XIV's Dutch war, Britain was first allied to France (Treaty of Dover, 1670), but quit the conflict in 1674. Consequently, (mainly Amsterdam-based) merchants implored William III not to prolong the conflict needlessly, in view of the loss of traffic to the British (IsRAEL, The Dutch Republic, op. cit., p. 824).

206 IsRAEL, The Dutch Republic, op. cit., p. 1001-1002. Since 1647, Spain and the Spanish Americas were of paramount importance to the Amsterdam trade (ibid., p. 783).

207 Jean Dureng, Le Duc de Bourbon et l'Angleterre 1723-1726 (diss. doc.), Toulouse, impr. Du Rapide, 1911, p. 48.

208 VATTEL, Le Droit des gens, op. cit., Book III, $\int$ 88: Le Casus Foederis [...] se trouve dans le concours des circonstances pour lesquelles le Traité a été fait, soit que ces circonstances y soient marquées expressément, soit qu'on les ait tacitement supposeés.

209 Treaty of Friendship and Alliance between George I and the States-General, Westminster, 6 February 1716 OS, on line at http://www.ieg-friedensvertraege.de/treaty/1716 II 6 B\%C3\%BCndniserneuerung/t-1225-18de.html?h=7 (last consulted on 14 March 2014). DuRENG, Le Duc de Bourbon, op. cit., p. 48. 
punishing participation in the Company with confiscation, lifelong imprisonment or death. Townshend followed the Dutch resident's point of view and suggested joint military action under the terms of the Triple Alliance ${ }^{210}$.

However, Ostend did not amount to a casus belli for France. In the words of Antoine Pecquet sr., senior adviser to Morville (1686-1732), secretary of state for foreign affairs: Les puissances maritimes ont leurs raisons de parler ainsy, Elles ressentent déjà les effets de l'Etablissement de la Compagnie d'Ostende qui leur cause un notable prejudice; mais a l'Egard de la France, il semble qu'elle doit considerer si pour elle un mal a venir, et peut etre tres eloigné doit l'engager dans une guerre où elle s'exposeroit à plus perdre qu'elle n'a à gagner ${ }^{211}$. Seen from Versailles, a slight tension between Charles VI and the Dutch Republic was preferable to a full-blown military conflict ${ }^{212}$.

In January 1724, the Congress of Cambrai was finally set to start major discussions ${ }^{213}$. Ostend and the recognition of Charles VI's Pragmatic Sanction were no core matters on the agenda, but were used in a reciprocal game of deterrence by Spain and the Imperial delegates Windischgrätz and Penterriedter, who happened to have been shareholders in the Company ${ }^{214}$. Dissatisfied with the slow advancement of the talks, the Spanish ambassador Pozzobueno ${ }^{215}$ presented a memorandum against the Ostend Company at George I's court. This might seem surprising, as Spain had but scant interest in the affair of the East India trade. However, Spain's first objective was to bring Charles VI to concessions at the Cambrai negotiating table. In that particular setting, France and Britain had an ambiguous role as both mediators (Treaty of the Quadruple Alliance, 1718) and allies of the King of Spain, the latter as the result of alliances posterior to the Quadruple Alliance itself (1721) ${ }^{216}$. A military conflict with Charles VI had been foreseen as a possibility ${ }^{217}$. For the Spanish, the lex posterior derogat priori-principle (recent treaties override older ones) had to play. The mediators, however, clung to the priority of the Utrecht settlement over incidental bilateral promises.

Moreover, the Dutch attitude in 1718 had left the British plenipotentiaries at the conference sceptical: The Dutch would not enter into any engagements which were taking for the Publick Tranquillity of Europe; and yet pretended to make use of them whenever their Private Interests were concerned. By which they would share the advantage

${ }^{210}$ Émile BourgeOIs, La Diplomatie secrète au XVIIIe siècle, Paris, Armand Collin, 1910, III, 375; DurENG, Duc de Bourbon, op. cit., p. 81. On British-Dutch relations in the 1720s, see Hugh L.A. DunTHORNE, The maritime powers 1721-1740. A study of Anglo-Dutch relations in the age of Walpole, New York, Garland, 1986.

211 AMAE, M\&D, France, 495, Antoine PECQUET sr. (1666-1728), "Reflexions sur les differens motifs qui ont pû determiner la France a prendre des Engagemens avec l'angleterre, la Hollande, et autres alliez", f. $2 \mathrm{r}^{\circ}$.

212 By doing just enough to encourage them in the Spirit of opposition rather than design to assist them heartily in obtaining satisfaction by a total Suppression of the Company at Ostend (NA, SP, 78, 174, Polwarth and Whitworth to Newcastle, Cambrai, 11 May 1724, ff. $1 \mathrm{v}^{\circ}-2 \mathrm{r}^{\circ}$.).

213 DHONDT, "La culture juridique pratique au Congrès de Cambrai (1722-1725)", in Revue d'Histoire Diplomatique CXXVII (2013), N³, p. 271-299.

214 Huisman, La Belgique Commerciale, op. cit., p. 243. See as well Jelten BAGUET, De Oostendse Compagnie, haar directeurs en de Oostenrijkse Bewindvoerders. Een casuïstische analyse van bun onderlinge interactie (1722-1731), UGent: Faculty of Arts and Philosophy (master thesis in history), 2012-2013

${ }^{215}$ Jacinto de Pozobueno y Belver (1659-1729), born in Ninove (Spanish Netherlands), military career under Charles II of Spain, governor of Trappani (Sicily, 1699), resident in London between 16 December 1720 and 17 January 1727 (Didier OZANAM \& Denise OZANAM, Les diplomates espagnols au XVIIIe siècle, Madrid/Bordeaux, Casa de Velázquez - Maison des Pays Ibériques, 1998 (Collection de la Casa de Velázquez; 64 - Collection de la Maison des Pays Ibériques; 72), p. 403.

216 Treaty between Louis XV and Philip V, Madrid, 27 March 1721, AMAE, Base des Pactes (http://www.diplomatie.gouv.fr/traites/affichetraite.do?accord=TRA17210007, last accessed 14 March 2013); Treaty between Louis XV, George I and Philip V, Madrid, 13 June 1721, CUD, VIII/2, nr. XV, p. 34-36.

${ }^{217}$ It is however interesting to note that Townshend insisted on a guarantee of non-invasion of the Austrian Netherlands, which Dubois adamantly refused (AMAE, CP, Angleterre, 336, Destouches to Dubois, London, 11 May 1721, f. $150 r^{\circ}$, quoted in BourGEOIS, Diplomatie secrète, op. cit., III, p. 274). 
without taking upon themselves any part of the risque or trouble for the future [...] They might have acted for themselves in the affair of the East India Trade, and would then have been intitled to the best assistance their Friends could give them ${ }^{218}$.

France and Britain insisted on the vagueness of promises made to Philip V, inter alia the restitution of Gibraltar, which was constitutionally impossible for George ${ }^{219}$. Frustrated with the slow course of affairs, Spain tried to provoke a conflict between Charles VI and the mediators in other issues, such as the Ostend Company. The latter was not foreseen as part of the agenda in Cambrai. The congress was solely directed towards the final details of the Spanish Succession quarrel. The Imperial delegations could retort by bringing the recognition of Charles VI's succession on the table and supported reprisals in case of British or Dutch depredations on the Ostend Company's trade. This deadlock made the conference grind to a halt.

Mare liberum, pactis apertum! Cursing in the public coffee-house of Europe

Les Couronnes de France \& d'Espagne demeurent separées \& désunies [...] Leurs Majestez Royales prendront un soin sincere \& feront leurs efforts, afin que rien ne donne atteinte à ce fondement du salut public, ni ne puisse l'ébranler

Art. VI, Treaty of Peace between Louis XIV and Queen Anne, Utrecht, 11 April $1713^{220}$

As expounded previously (I.B), Neny and Dumont had challenged the contractual basis for the exclusion of Charles VI's Belgian subjects. They lost the battle in doctrine, as e.g. Vattel copied Barbeyrac's proDutch point of view concerning the alienability of the right to navigation on the high seas ${ }^{221}$. Diplomatic practice, however, added a legal performance that brought the very essence of treaty law to the front. If Westerveen and Barbeyrac founded the exclusion on a voluntary act by two sovereigns, they could hardly oppose a norm of the same value.

On 30 April/1 May 1725, Charles VI and Philip V provoked what seemed a revolution in the European diplomatic system ${ }^{222}$. They had been bitter enemies. At Cambrai, France and Britain got exasperated by their unwillingness to compromise. Whereas, in 1717, Charles VI had sent out corsairs from Ostend to cruise on Philip V's vessels 223 , both men were all of a sudden reconciled, boosting the Ostend trade. Philip's clandestine agent in Vienna, the Dutch “adventurer224" Johan Willem Ripperda (1682-1737), transmitted Elisabeth Farnese's wrath with the disloyal behaviour of France. The Duke of Bourbon (16921740), Prime Minister of the 14 year-old Louis XV after Orléans' decease, had decided to cancel the projected marriage between the still minor infant Maria Anna Victoria ( $\left.{ }^{\circ} 1718\right)$ and his sovereign ( $\left.{ }^{\circ} 1710\right)$. Moreover, during the Cambrai talks, French and British mediators played out Spain and Austria against each other. Ripperda persuaded Eugene of Savoy and Sinzendorf to bury the war hatchet and jointly oppose the mediators. Coupled with a projected marriage between Don Carlos ( $\left.{ }^{\circ} 1716\right)$, son of Philip V

218 Polwarth and Whitworth (plenipotentiaries for George I) to the Duke of Newcastle (secretary of State for the Southern Department), Cambrai, 11 May 1724, very private, SP, 78, 174, f. 1 $\mathrm{v}^{\circ}$.

219 The letter of George I to Philip V, dated 12 June 1721, can be found in AMAE, CP (suppl.), Angleterre, 7, f. $14 \mathrm{r}^{\circ}$. Its wording explicitly refers to parliamentary consent : Je ne ballance plus a assurer V.M. de ma promptitude à la satisfaire par raport à sa demande touchant la restitution de Gibraltar lui promettant de me servir des premieres occasions favorables $p[\mathrm{ou}] \mathrm{r}$ regler cet article du consentement de mon Parlem[en]t.

${ }^{220}$ CUD VIII/1, nr. CLI, p. 340.

221 VATTEL, Le droit des Gens, op. cit., Book I, \284.

222 Peace Treaty between Charles VI and Philip V, Vienna, 30 April/1 May 1725, CUD VIII/2, nr. XXXVI, p. 106-113; Treaty of Alliance between Charles VI and Philip V, Vienna, 30 April/1 May 1725, CUD VIII/2, nr. XXXVIII, p. 113-114; Peace Treaty between Charles VI (as Holy Roman Emperor) and Philip V, Vienna, 7 June 1725, CUD VIII/2, nr. XXXIX, p. 121-125.

223 WeSTERVEEN, “Tweede Vertoog”, in Europische Mercurius XXXV, p. 247.

224 BELY, Les relations internationales en Europe, XVIIe-XVIIIe siècles, Paris, PUF, 1992, (Thémis), p. 459. 
and Elisabeth Farnese, with an archduchess (one of Charles VI's three daughters), the new alliance could dominate the continent ${ }^{225}$.

The Commercial treaty reversed the prevailing legal logic and confirmed Charles' Belgian subject's right to navigation. Whereas Neny had argued that the liberty of the Southern Netherlanders rested on a pure application of peremptory natural law, the VOC had preferred stressing self-inflicted limitations on this right. Yet, the latter strand of argumentation came under pressure. If access to the high seas had been conditional on the absence of a bilaterally concluded renunciation by the ruling Spanish monarch in the $17^{\text {th }}$ century, the latter could cease to exist decades later, when his successor Philip V explicitly opened the Spanish Indies to merchants under Charles VI's sovereignty. Spain could incur a separate bilateral liability to the Dutch Republic, if the Treaty of Munster was still operative, in the sense read by Barbeyrac and Westerveen. Yet, between the new ruler of the Southern Netherlands and the sovereign in the Spanish Indies, no impediment existed.

The Treaty of Commerce and Navigation negotiated by Ripperda merits more attention than it has hitherto received ${ }^{226}$. Dutch arguments according to which the Spanish exclusion of Philip IV's former subjects in the Southern Netherlands was a proof of the possibility to conventionally close navigation on the high seas, were completely shipwrecked, to sink to the bottom of the sea at dazzling speed. Philip V allowed the "Belgians" what had been taken away under his Habsburg predecessors. The Dutch East and West India Companies' legal objections had been spectacularly emasculated: if a treaty could have closed the sea to Belgian entrepreneurs, it had now been opened at large by a new one 227 .

In 47 articles, drafted by Du Mont228, Philip V conceded extensive privileges to the subjects of Charles VI operating on Spanish soil (art. XXI-XXIV) 229 , as well as to the Ostend trade. Unlimited access to the Spanish colonies (art. IV, Treaty of Alliance, art. II, IX and XIII, Treaty of Commerce and Navigation) shredded the commercial dominance obtained by Britain in the War of the Spanish Succession. Next to Philip's renunciation to the French throne, Britain had imposed an annual so-called "permission vessel" sailing from Cadiz to the Spanish Americas, as well as the contract allotting the monopoly on the black slave trade, the so-called Asiento de Negros ${ }^{230}$. Philip V took the liberty to modify the pecking order

225 DHONDT, "Law on the Diplomatic Stage: The 1725 Ripperda Treaty", in V. DragANOVA et al (eds.), Inszenierung des Rechts - The Law on Stage, München, Meidenbauer Verlag, 2011 (6 Jahrbuch Junge Rechtsgeschichte Yearbook of Young Legal History 2010), p. 303-324; Max BRAuBACH, Prinz Eugen von Savoyen; eine Biographie, München, Oldenbourg, 1964, III, p. 226-236; Sytze VAN DER VEEN, Spaanse Groninger in Marokko. De levens van Johan Willem Ripperda (1682-1737), Amsterdam, Bert Bakker, 2007, p. 228-288.

226 Treay of Navigation and Commerce between Charles VI and Philip V, Vienna, 1 May 1725, CUD, VIII/2, nr. XXXVIII, p. 114-121; E.g. Bustos RodríGueZ, Le Consulat des Flamands à Cadix après la Paix d'Utrecht (17131730): Jacques Vermolen”, in PARMENTIER \& SPANOGHE (eds.), Urbis in Orbem, op. cit., p. 119-120 saw parallels in earlier proposals by Jacques Vermolen, Austrian consul in Cadix. Alfred Baudrillart (Philippe V et la cour de France, IV, 186) mentioned parallels with the Most Favoured Nation Status granted to the Hanse.

${ }_{227} \mathrm{Du}$ Mont saw precedents throughout the seventeenth century: e.g. when Spain concluded bilateral treaties of commerce and navigation, it had to consent to the other contracting party the same advantages and privileges enjoyed by the Dutch, e.g. in the Anglo-Spanish Treaty of 23 May 1667 (DU MonT, La Vérité du fait, op. cit., p. 15).

228 GEHLING, Saint-Saphorin, op. cit., p. 209; Grete MECENSEFFy, Karl VI. spanische Bündnispolitik, 1725 1729. Ein Beitrag zur österreichischen Aussenpolitik des 18. Jabrbunderts, Innsbruck, Universitäts-Verlag Wagner, 1934, p. 30.

229 Ana HeRnANDEZ CRESPO, "El Interés público y el interés particular: una visión comparativa en las representaciones de los mercaderes flamencos en la corte de Felipe V", in Réne VermeIR, Maurits EBBEN \& Raymond Fagel (eds.), Agentes e Identidades en Movimiento. España y los Países Bajos Siglos xvi-XVIII, Madrid, Silex, 2011, p. 373-402. Du Mont, who drafted the treaty, explicitly referred to the pre-existing "Confreres de la Chapelle de St Andre" in his own treatise on Ostend (DU MONT, La Vérité du fait, op. cit., p. 20).

230 Georges SCELLE, Histoire politique de la traite négière aux Indes de Castille : contrats et traités d'Assiento, Paris, Larose \& Tenin, 1906 ; Andrea WeINDL, “The Asiento de Negros and International Law”, in JHIL X (2008), No. 2, p. $229-258$. 
between European trade partners (art. XLVII ${ }^{231}$ ), imposed at Utrecht, which equalled cursing in the public coffee-house of Europe. All factories and trade posts in the East Indies were recognized. Letters of reprisal against Spanish or Habsburg subjects cancelled, and seizures against common enemies projected (art. XLI-XLIII). Finally, the "Flemish" nations in Spain obtained their own extraterritorial jurisdiction (art. XXVII-XXX) and could count on a bilateral system of judiciary assistance and ambassadorial services for international successions, which guaranteed the transmission of family patrimony to individual merchants (art. XXXI-XXXII).

The "Austro-Spanish commercial cartel" thus constructed not only threatened the geopolitical balance in Europe, but British and Dutch commercial primacy as well232. In 1725-1726, the Ostend Company controlled half of European tea imports ${ }^{233}$. The alliance was drafted to the detriment of Spain in general. The projected marriage between Don Carlos and one of the Austrian Archduchesses was hypothetical, but annual payments amounting to 3 million florins to the court of Vienna were not ${ }^{234}$. Already in June 1725 , protest against the treaty appeared in the Madrilene press ${ }^{235}$.

The Republic had no other choice but to join the Alliance of Hanover (3 September 172523). Not only to supress the Ostend Company. The combination of Spain and Austria was a potential geopolitical threat. Moreover, a conflict with them could escalate if Brandenburg-Prussia stepped in on the side of the Emperor, which would endanger the Republic's eastern border ${ }^{237}$.

231 "We have convened that everything granted in favour of the subjects of the British nation by the Treaties of Madrid (23 May 1667, 1 July 1670), as well as the Peace and Commerce treaties done at Utrecht in 1713, or posterior conventions, \& which is not expressed, or sufficiently explained in the present, will be held for expressly inserted, in favour of the subjects of [Charles VI], for as far as they will be applicable to them. Idem for all that has been accorded to the subjects of the States-General, by the Peace Treaty of Munster (1648), the Marine Treaty of The Hague (1650), or the Peace and Commerce Treaty of Utrecht (1714)" (my translation from Latin).

232 SIMMS, Three Victories and a Defeat, op. cit., p. 185.

${ }^{233}$ Hanna HodAcs \& Leos MÜLLER, "European Market for Tea and the Swedish East India Company, c. 1730-1760", in: Maxine BERG (ed.), Goods from the East: Trading Eurasia 1600-1830. Conference at the Palazzo PesaroPapafava, Venice, 11 -13 January 2013 (forthcoming).

234 Basil Williams, The Whig Supremacy 1714-1760, Oxford, Clarendon Press, 1900 (The Oxford History of England), p. 255.

235 BAUdrillart, Philippe V et la cour de France, op. cit., III, p. 202.

236 Treaty of Alliance between George I, Louis XV and Frederick William I, Hanover, 3 September 1725, CUD VIII/2, nr. XLI, p. 127-129; John F. CHANCE, The Alliance of Hanover. A study of British foreign policy in the last years of George I, London, John Murray, 1923; DHONDT, "So Great A Revolution: Charles Townshend and the Partition of the Austrian Netherlands, September 1725”, Dutch Crossing: Journal of Low Countries Studies XXXVI (2012), No. 1 (Mar), p. 50-68; GIBBS, "Britain and the Alliance of Hanover, April 1725-February 1726" in EHR LXXIII (1958), No. 288 (Jul), p. 404-430.

${ }^{237}$ Conflicts with the Bishophric of Münster had been notorious in the $17^{\text {th }}$ century, Prussian acquisitions at the Treaty of Utrecht and Frederick William I's support for the House Orange against the republican party in the United Provinces had increased tension. Israel, Dutch Republic, 989 and Kristof Selleslach, "Amitie sincère?" Het prinsbisdom Münster en de Haagse Alliantie tijdens de Spaanse Successieoorlog (1701-1714) (Master Thesis in History), Leuven, KULeuven, 2001. Frederick William I (1688-1740), on one hand, was still claiming the title of Prince of Orange after the decease of Johan Willem Friso, nephew of William III (Treaty between Frederick William I and the StatesGeneral, on the Partition and Accomodation of the Succession of the House of Orange, Berlin, 14 May-16 June 1732, Rousset DE Missy, Supplément au Corps Universel Diplomatique du droit des gens, Amsterdam/The Hague, Janssons à Waesberghe, 1739, II, nr. CLVII, p. 335-340). and, on the other hand had obtained territorial enlargement at Utrecht, turning Maastricht, Roermond and Venlo into enclaves. Next, the Hohenzollern pretentions on the duchies of Jülich and Berg, situated in the Rhineland, included the seigneurie of Ravenstein, an enclave in the Generality Lands (ISRAEL, The Dutch Republic, op. cit., p. 989-991 and DHONDT, "German or European ? Jülich and Berg between Imperial and Public International Law", Beiträge zur Rechtsgeschichte Österreichs: recht [durch] setzen: Making Things Legal. Gesetzgebung und prozessuale Wirklichkeit in den europäischen Rechtstraditionen, Hrsg. von K. STAUDIGL-CHIECHOWICZ e.a., III (2013), Nr. 2, p. 355-362). 


\section{Conclusion}

The suppression of the Ostend Company became central to the Republic's foreign policy in the 1720s. Pensioner Simon Slingelandt (1664-1736), in function from 1727 on, even convinced the City of Amsterdam to accept a rise in the verponding (real estate tax) pursuant to a recalculation of the land register, with the prospect of hard action against the competitor in the Southern Netherlands ${ }^{238}$.

The managers of European international relations between 1713 and 1740 avoided the sudden eruption of a continent-wide military conflict ${ }^{239}$. In order to succeed in this objective, all pending bilateral issues had to be solved conformable to the power consensus imposed by arms during the War of the Spanish Succession and translated into legal language at the conclusion of the peace treaties. Bilateral argumentation, such as that of the VOC, could not intervene in the conclusion of a treaty between Philip $\mathrm{V}$ and Charles VI, opening trade in the Indies to the Ostend Company. Yet, one overarching principle was the touchstone of all European affairs: the upholding of the European balance. By tying the commercial treaty to a projected marriage between Don Carlos and an Austrian archduchess, Charles VI and Philip V had openly violated the balance of power. The latter was not a mere power configuration, but the expression of a system of legal hierarchy, delimitating the scope of any legal instrument. Between treaty law and constitutional law ${ }^{240}$, but between fundamental and secondary treaty norms as well. At the draft of the Ripperda treaties, the balance principle was invoked, but only to obscure its violation in the ensuing paragraphs ${ }^{241}$.

At the Congress of Soissons (1728-1730), Horatio Walpole (1678-1757) and William Stanhope (16901756), British plenipotentiaries, insisted on seeing the Ostend Company as an application of a more general reasoning ${ }^{242}$. As an accessorium to the general power distribution in Europe, its legal status fell under the 1713 Great Power consensus, which was still intact. The countervailing Dutch arguments, presented by Slingeland ${ }^{243}$, according to which Philip V could not have opened access to the Spanish Indies without prior consultation of the Dutch Republic, with whom he had to respect the Treaty of Munster just as Charlres VI had, or without violation of the loix fondamentales de l'Espagne, forbidding access to and trade in the Indies for all foreign nations, were not relevant any more. Multilateral decision-making, implying Charles VI's consent to drop the Company successively in $1727^{244}$ and $1731^{245}$, decided on its fate. Yet,

238 J.A.F. DE JONGSTE, "Een bewind op zijn smalst. Het politiek bedrijf in de jaren 1727-1747”, in Dirk Peter BLOK, Walter PREVEnIER et al. (eds.), Algemene Geschiedenis der Nederlanden, Haarlem, Fibula-Van Dishoeck, 1980, IX, 47; IsRAEL, The Dutch Republic, op. cit., p. 993.

239 DHONDT, "Balance of Power Language and Mediation Rituals: The Quadruple Alliance's Italian Investitures (1718-1727)", in 2000: The European Journal XIII (2012), No. 2 (Dec), p. 10-13.

240 If looked at Philip V's or Orléans' renunciations or the recognition of George I to the detriment of James III. DHONDT, "From Contract to Treaty".

${ }^{241}$ DHONDT, "Law on the Diplomatic Stage".

242 We observed that France has the same grounds with His Maj[es]ty \& the States to complain against the Treaty of Commerce concluded at Vienna, \& having jointly with them entered into the Treaty of Hanover for obviating the Mischiefs apprehended from the Treatys made between the Emperor \& Spain, it would have a better appearance of Union between the allies, if France, instead of having a particular article for preserving their Rights and Privileges of Trade with Spain as seems intended [...] should be made a party to this article jointly with His Majesty and the States. (NA, SP, 78, 188, Notes on a conference between Chauvelin (French Secretary of State for Foreign Affairs, 1727-1737), Horatio Walpole (British envoy extraordinary at Paris 1723-1730) and William Stanhope (ambassador in Madrid, 1721-1727, Secretary of State for the Northern Department, 1730-1740) on a draft peace treaty for the Congress of Soissons, Paris, s.d., f. 551vº).

${ }^{243}$ NA, SP, 78, 188, "Memoire des Demandes faites au Congrés de Soissons par les Plenipotentiaires des Provinces Unives des Paÿs-Bas, presenté au Nom des Alliés d'Hanover aux alliés de Vienne", Soissons, 20 June 1728 , f. $527 v^{\circ}$. The memorandum took over arguments from Westerveen and de la Bassecourt's reactions ("les fougeux publicistes", HuISMAN, La Belgique commerciale, p. 332) to the Ripperda commercial treaty. I limited myself to the most substantial memoranda on the Ostend question. See further: DE PAUW, Mare Liberum, op. cit. and HUISMAN, La Belgique commerciale, op. cit., p. 379-403.

244 Art. I Preliminary Articles concluded between Charles VI and the Allies of Hanover, Paris, 31 May 1727, CUD VIII/2, nr. LVII, p. 146-148. 
this process had not been arbitrary or induced by domestic preoccupations, but was the expression of an implicit legal logic in the structure of day-to-day diplomatic process.

245 Art. V, Treaty of Alliance between Charles VI and George II, Vienna, 19 March 1731, Rousset, Supplément, II, nr. XLII, p. 288-291. 